\title{
EU free movement law and the children of rainbow families: children of a lesser God?
}

Article

Accepted Version

Tryfonidou, A. (2019) EU free movement law and the children of rainbow families: children of a lesser God? Yearbook of European Law, 38. pp. 220-266. ISSN 2045-0044 doi: https://doi.org/10.1093/yel/yez001 Available at https://centaur.reading.ac.uk/82826/

It is advisable to refer to the publisher's version if you intend to cite from the work. See Guidance on citing.

To link to this article DOI: http://dx.doi.org/10.1093/yel/yez001

Publisher: Oxford University Press

All outputs in CentAUR are protected by Intellectual Property Rights law, including copyright law. Copyright and IPR is retained by the creators or other copyright holders. Terms and conditions for use of this material are defined in the End User Agreement.

\section{www.reading.ac.uk/centaur}

\section{CentAUR}

Central Archive at the University of Reading

Reading's research outputs online 


\title{
EU Free Movement Law and the Children of Rainbow Families: Children of a Lesser God?
}

\author{
Alina Tryfonidou*
}

\begin{abstract}
EU citizens and - through them - certain of their family members, derive from EU law the right to move between EU Member States and reside in the Member State of their choice. This right is enjoyed by all Union citizens irrespective of their sexual orientation. However, when rainbow families (i.e. families comprised of a same-sex couple and their child(ren)) exercise this right and move to a Member State which does not provide legal recognition to same-sex couples and/or their families, they are faced with the possibility that that Member State will refuse to legally recognise the familial ties among all or some members of the family, as these have been legally established elsewhere. This means that such families are not treated in the same way as the typical nuclear family which has an opposite-sex, married, couple with children as its basis: the familial links among the members of such families are only very rarely - if ever - legally contested. The question that emerges, therefore, is whether the severance in the host Member State of the legal ties among the members of rainbow families, amounts to a breach of EU law. This article will focus on the parent-child relationship and will examine the above question by taking a child-centred approach: does the refusal of the host Member State to legally recognise the relationship between a child and one or both of his same-sex parents when the family moves to its territory, amount to a breach of any of the rights that the child enjoys under EU law?
\end{abstract}

\section{KEYWORDS}

EU law; EU free movement; Fundamental Rights; LGBT+ rights; Rainbow Families; Children's Rights.

\section{Introduction}

European Union (EU) citizens, ${ }^{1}$ and - through them - (certain of) their family members, derive from EU law the right to move between EU Member States and reside in the Member State of their choice. This right is enjoyed by all Union citizens irrespective of their sexual orientation. ${ }^{2}$ However, when rainbow families (i.e. families comprised of a same-sex couple and their child(ren $)^{3}$ ) move to a Member State which

* $\quad$ Professor of Law, University of Reading. I am extremely grateful to Thérèse Callus, Loveday Hodson, Dimitry Kochenov, and Björn Sieverding, for their invaluable comments on an earlier draft of this article; needless to say, all errors remain mine. I would, also, like to thank the Law School, University of Reading, for the period of research leave it has generously granted me for writing this article.

1 Article 20 TFEU provides that every person holding the nationality of an EU Member State is an EU citizen.

2 As Jessurun D'Oliveira has aptly put it, 'freedom of movement is granted in Article 3 EEC to persons (workers and others); lesbians and gay men are persons; thus lesbians and gay men enjoy freedom of movement' - H. U. Jessurun d'Oliveira, 'Lesbians and Gays and the Freedom of Movement of Persons' in K. Waaldijk and A. Clapham (eds), Homosexuality: A European Community Issue (Martinus Nijhoff, 1993) 294.

3 Rainbow families can, also, involve more complex parenting configurations, where the parental roles are divided among more than two persons (usually, among the two biological parents plus the partner of one or both and/or a best friend who donates a sperm or an egg). Due to lack of 
does not provide legal recognition to same-sex couples and/or their families in its territory, they are faced with the possibility that that Member State will refuse to legally recognise the familial ties among all or some members of the family, as these have been legally established elsewhere. This means that such families are not treated in the same way as the typical nuclear family which has an opposite-sex, married, couple with its biologically-linked children as its basis: the familial links among the members of such families are only very rarely - if ever - legally contested. The question that emerges, therefore, is whether the refusal of some Member States to legally recognise the familial links among the members of rainbow families that move to their territory in exercise of EU free movement rights, amounts to a breach of EU law.

Since the issue of the cross-border legal recognition of same-sex relationships in the EU context has been analysed in detail elsewhere, ${ }^{4}$ this article will merely concern the cross-border legal recognition of the parent-child relationship in rainbow families. This is an issue that, to date, has been mainly left untouched by legal commentators, as there has not been a single contribution which conclusively deals with this issue. This article, therefore, aims, exactly, to fill this gap in the literature. In addition, this article aims to provide a point of reference for all rainbow families that seek to enforce their right to free movement under EU law, as well as non-governmental organisations which have as their mission to protect the rights of such families. ${ }^{5}$ As will be explained in subsequent parts of this article, the non-recognition of the familial links among the members of rainbow families has a host of negative legal, practical, and psychological consequences for those families. It is, therefore, important to provide a clear analysis of why the severance of the legal ties among a child and one or both of his/her samesex parents in situations where the family has exercised EU free movement rights, amounts to a breach of EU law.

The question of the cross-border legal recognition of the parent-child relationship in rainbow families can be examined from two different angles: the adults' (parents') angle (i.e. the position of the parents who are in a same-sex relationship) and the

space, this article shall, however, only consider the position of the more 'traditional' rainbow families, where the parental roles are played by two persons who comprise a same-sex couple. For an interesting analysis of the question of non-binary unions in EU Member States and under EU law see D. Kochenov and U. Belavusau, 'Same-Sex Spouses: More Free Movement, but What about Marriage? The Romanian State, Sodom and Gomorrah, and the Case of Coman' (2019) 56 Common Market Law Review (forthcoming).

4 See, inter alia, A. Tryfonidou, 'EU Free Movement Law and the Legal Recognition of Same-Sex Relationships: The Case for Mutual Recognition' (2015) 21 Columbia Journal of European Law 195; U. Belavusau and D. Kochenov, 'Federalizing Legal Opportunities for LGBT Movements in the Growing EU' in K. Slootmaeckers, H. Touquet, and P. Vermeersch (eds), The EU Enlargement and Gay Politics: The Impact of Eastern Enlargement on Rights, Activism and Prejudice (Palgrave 2016); D. Kochenov, 'On Options of Citizens and Moral Choices of States: Gays and European Federalism' (2009) 33 Fordham International Law Journal 156; K. Lenaerts, 'Federalism and the Rule of Law' (2011) 33 Fordham International Law Journal 1338, 1355-1361; S. Titshaw, 'SameSex Spouses Lost in Translation? How to Interpret "Spouse" in the EU Family Migration Directives' (2016) 34 Boston University International Law Journal 45.

5 In the European context, the Network of European LGBTIQ Families Associations (NELFA) has as its aim to advance the rights of rainbow families across Europe. 
child's angle (i.e. the position of the child whose relationship with one or both parents may not be legally recognised when the family moves to another Member State). ${ }^{6} \mathrm{~A}$ complete examination of both angles would, nonetheless, be worthy of a monograph in its own right. Accordingly, in this article I have chosen to examine the question solely from the perspective of the child, not least, for the practical reason that in all academic and other discussions conducted so far around this matter, this angle has been largely ignored. This is not surprising, as children's voices tend to be too often absent in disputes involving the recognition of the parent-child relationship and human rights jurisprudence related to sexual orientation has mostly been moulded on the experiences of adults. ${ }^{7}$

The article will begin by documenting, in section II, the situation with regards to parenting by same-sex couples in a single-country context: which EU Member States allow same-sex couples to become - and be recognised legally as - co-parents in their territory? Section III will, then, proceed to examine briefly how children can benefit from family reunification and related rights granted by EU law in situations that involve the exercise of EU free movement rights, and Section IV will demonstrate the difficulties that rainbow families face when they move between EU Member States. Section $V$ will then seek to explain why it is not permissible for EU Member States to refuse to recognise the familial links - as these have been established elsewhere among the members of rainbow families that have moved to their territory. It will be seen that such a refusal amounts to, both, a breach of the EU free movement of persons provisions and of a number of fundamental human rights which are protected under EU law. Accordingly, the main conclusion of the article will be that the legal tools that the EU already has at its disposal, namely, the free movement provisions and fundamental (human) rights, are sufficient for providing an appropriate solution to the problems faced by rainbow families when they exercise their free movement rights. What is needed, therefore, is for the EU to take a clear stance on the matter and to inform the Member States that EU law requires them to recognise, for all legal purposes, the familial ties among the members of a rainbow family coming from another Member State, as these have been established elsewhere.

$6 \quad$ J. Rijpma and N. Koffeman, 'Free Movement Rights for Same-Sex Couples Under EU Law: What Role to Play for the CJEU?' in D. Gallo, L. Paladini and P. Pustorino (eds), Same-Sex Couples Before National, Supranational and International Jurisdictions (Springer 2014) 461.

7 Report on Round Table on Rainbow Families: from mutual recognition of rights in the EU to national strategies on marriage equality and/or civil union laws, p. 4 (Report available at $<$ http://www.ilgaeurope.org/sites/default/files/20150618 ilga europe round table on rainbow families report.pdf> (accessed on 10.12.2018). The Report contrasts the approach of the European Court of Human Rights (ECtHR) in Gas and Dubois v. France, no. 25952/07, 2012 (where the child was not a party to the case) with that in X and Others v. Austria, no. 19010/07, 2013 (where the child was a party to the case). See, also, L. Hodson, 'Ties That Bind: Towards a Child-Centred Approach to Lesbian, Gay, Bi-Sexual and Transgender Families under the ECHR' (2012) 20 International Journal of Children's Rights 501. 


\section{Same-Sex Couples and Parental Rights in EU Member States: The Current Position}

The nuclear family, consisting of different-sex married spouses and their biologicallylinked children, was never the only form of family that existed, though, it is still 'the gold standard against which all other family types are assessed'. ${ }^{8}$ Nonetheless, 'the family' is a flexible and adaptable unit and recent years have seen an increase in alternative families, many families now consisting of (unmarried) cohabitants and their children, children and their parents and step-parents, children and their single parent, and children and their same-sex parents. ${ }^{9}$ The law, therefore, not only needs to recognise such alternative families, ${ }^{10}$ but, also, to provide a system that is sensitive and responsive to their own specific needs. ${ }^{11}$

Children in rainbow families can be from previous opposite-sex or same-sex relationships, the result of (initially) single parenthood, or the result of planned parenthood where the same-sex couple wishes to embark on parenting together. ${ }^{12}$ It is, of course, well-known that despite impressive advances in medicine and technology, same-sex couples are still incapable of having children who will be genetically related to both members of the couple. ${ }^{13}$ Such couples can, however,

8 S. Golombok, Modern Families: Parents and Children in New Family Forms (CUP, 2015) 4. See, also, A. Singer, 'The Right of the Child to Parents' in K. Boele-Woelki, N. Dethloff and W. Gephart (eds), Family Law and Culture in Europe: Developments, Challenges and Opportunities (Intersentia, 2014) 137-138.

S. Golombok (above n. 8) 3; L. Hodson (above n. 7) 502-504.

C. McGlynn, Families and the European Union: Law, Politics and Pluralism (CUP 2006) 39-41 and Chapters 4 and 5; L. Gonzalez, "With Liberty and Justice for All [Families]": The Modern American Same-Sex Family' (2011) 23 St. Thomas Law Review 293.

Opinion of AG Szpunar in Case C-335/17, Babanarakis EU:C:2018:242, para. 29. For an analysis of this argument see, inter alia, A. Bainham, 'Family Law in a Pluralistic Society' (1995) 22 Journal of Law and Society 234.

M. M. Winkler, 'Same-Sex Families Across Borders' in D. Gallo, L. Paladini and P. Pustorino (eds), Same-Sex Couples Before National, Supranational and International Jurisdictions (Springer 2014) 381.

It is true that in the last few years, so-called 'three-parent babies' have been created with the use of a technique that mixes DNA from three persons. Nonetheless, so far, such techniques have only been used in situations where a woman has faulty mitochondria and, thus, needs those mitochondria to be exchanged with those of a healthy, unrelated, female egg donor in order to ensure that genetic diseases will not be passed from the mother to the child - see S. Reardon, 'Genetic details of controversial "three-parent baby" revealed', (2017) Nature $<$ https://www.nature.com/news/genetic-details-of-controversial-three-parent-baby-revealed1.21761> (accessed on 08.01.2019); 'UK doctors select first women to have "three-person babies"', The Guardian, 12018 <https://www.theguardian.com/science/2018/feb/01/permission-given-to-create-britains-

first-three-person-babies $>$ (accessed on 08.01.2019). It is important to note that at the moment, there has been no discussion about creating 'three-parent babies' using the above technique in situations involving a healthy mother, for the purpose of overcoming the inability of a same-sex couple to have a child that is biologically related to both members of the couple. Nonetheless, what appear more promising for same-sex couples are recent experiments with mice that have shown that synthetic sperm and eggs can be created using stem cell technology, which can, potentially, enable same-sex couples to have children who are biologically related to both 
become de facto joint parents in a number of ways, such as through donor insemination (known or anonymous), assisted reproductive technologies, surrogacy, by becoming the joint parents of children from a prior relationship of one of the members of the couple (step-child adoption), or through adoption. ${ }^{14}$ This means that in some situations, one of the members of the couple will be biologically connected to the child (e.g. when one of the female partners in a same-sex couple undergoes medically assisted procreation using her own egg or the egg of her partner), ${ }^{15}$ whilst in other situations (e.g. adoption or surrogacy used by a male same-sex couple with sperm donated from a third party) the child will be genetically linked to neither of the members of the couple. Rainbow families, therefore, challenge some of the main assumptions that underpin the nuclear family ideal, namely, that a family is comprised of an opposite-sex couple and that its children are biological descendants of their primary caregivers. ${ }^{16}$

In terms of same-sex parenthood, the important questions that arise are whether, under a specific legal system, same-sex couples a) are allowed de facto to become the parents of a child and $b$ ) they can be recognised legally as the joint legal parents of the child (either automatically or after taking specific steps (e.g. adoption)).

members of the couple - see, for instance, 'Artificial sperm and wombs offer new means of reproduction', Financial Times, 8 December 2017 <https://www.ft.com/content/0f9b51d6c565-11e7-b30e-a7c1c7c13aab> (accessed on 08.02. 2019).

For a clear explanation of these options see T. Amos and J. Rainer, 'Parenthood for Same-Sex Couples in the European Union: Key Challenges' in K. Boele-Woelki and A. Fuchs (eds), Same-Sex Relationships and Beyond: Gender Matters in the EU (Intersentia, 2017).

15 In most EU Member States, motherhood is legally defined through birth and this is so even following advances in medicine which have made egg donation possible. This means that in rainbow families where the parents of the child are two women, in Member States which do not recognise same-sex couples as the joint parents of a child, the legal mother of the child will be the woman who gives birth to the child, irrespective of whether she is, also, the genetic mother of the child. Hence, in situations of intra-partner egg donation, the genetic mother of the child (the mother who provided the egg) will not be recognised in law as the mother of the child. For a brief discussion of this from a philosophical angle see P. Le Coz, 'What does it mean to be a mother in this age of assisted reproductive technology?' in B. Feuillet-Liger, T. Callus and K. Orfali (eds), Reproductive Technology and Changing Perceptions of Parenthood around the world (Bruylant, 2014).

16 In other words, as explained by Déchaux, rainbow families challenge the 'dominant kinship model' - see J-H. Déchaux, 'The Challenges of the New Reproductive Technologies: How Kinship Enters Politics' in B. Feuillet-Liger, T. Callus and K. Orfali (eds), Reproductive Technology and Changing Perceptions of Parenthood around the world (Bruylant, 2014). As explained by the above author, 'kinship model' 'is the series of laws, principles and beliefs which specify for a society or a given social group a definition of kinship, that is to say which attribute children to adults designated as parents' (p. 312). The 'dominant kinship model' 'is bilateral (a father and a mother), exclusive (only one father, only one mother) and bio-centric (the father and mother are presumed to be the progenitors of the child, since a man and a woman are needed to have a child)' (p. 314). It should be noted, however, that 'no kinship model is immutable' (p. 312) and, thus, the legal recognition of parenthood in rainbow families simply requires the adoption of a different type of kinship model and, in particular, one which is not bio-centric whilst it can continue being bilateral, provided that the latter does not require that the parents are of different sexes. 
The lack of EU competence on the matter as well as the lack of guidance at European level mean that the parental rights that same-sex couples enjoy at national level vary considerably throughout the EU. The most recent edition (at the time of writing) of ILGA Europe's Rainbow map, ${ }^{17}$ demonstrates that only a minority of EU Member States provide full parental rights to same-sex couples: '[t]he idea that in order to thrive a child needs two parents of different sex who are in a committed relationship, translates in many jurisdictions into laws precluding different-sex cohabitants from adopting children and same-sex partners from both being acknowledged as legal parents of their children'. ${ }^{18}$

At the moment of writing, joint adoption by same-sex couples is only allowed in half of the EU Member States, ${ }^{19}$ as is the case for step-child adoption by same-sex couples. ${ }^{20}$ Surrogacy is largely prohibited across EU Member States, ${ }^{21}$ and most Member States even refuse to recognise children born of surrogacy arrangements made in other countries. ${ }^{22}$ This limits the parenting options for male same-sex couples to adoption. ${ }^{23}$ The law allows medically assisted procreation by (female) same-sex couples (as a couple) in only twelve EU Member States, ${ }^{24}$ whilst it is only in ten EU Member States that same-sex couples enjoy automatic recognition as co-parents. ${ }^{25}$

17 See ILGA Europe Rainbow Europe Package: Annual Review and Rainbow Europe Map <https://www.ilga-europe.org/resources/rainbow-europe/rainbow-europe-2018> (accessed on 22.11. 2018).

18 N. Nikolina, 'Evolution of parenting rights in Europe - a comparative case study about questions in section 3 of the LawsAndFamilies Database' in K. Waaldijk, More and more together: Legal family formats for same-sex and different-sex couples in European countries: Comparative analysis of data in the LawsAndFamilies Database, Working Paper 75 (2017) in the FamiliesandSocieties Woper Series, $<$ https://openaccess.leidenuniv.nl/bitstream/handle/1887/54628/Waaldijk\%20\%20More\%20and\%20more\%20together\%20\%20FamiliesAndSocietiesWorkingPaper\%2075\%282017\%29.pdf?sequence $=3>$ (accessed on 22.11.2018), 102.

19 Austria, Belgium, Denmark, Finland, France, Germany, Ireland, Luxembourg, Malta, Netherlands, Portugal, Spain, Sweden, and the UK.

20 Austria, Belgium, Denmark, Finland, France, Germany, Luxembourg, Malta, Netherlands, Portugal, Slovenia, Spain, Sweden, and the UK.

21 For a comparative study of EU Member States' approach to surrogacy see L. Brunet and others, A Comparative Study on the Regime of Surrogacy in EU Member States (2013), <http://www.europarl.europa.eu/RegData/etudes/STUD/2013/474403/IPOL-

JURI ET(2013)474403 EN.pdf> (accessed on 12.10.2018). For a recent chapter on surrogacy in the EU see I. Rein-Lescastereyres, 'Recent Case Law on Cross-Border Surrogacy' in Boele-Woelki and A. Fuchs (eds), Same-Sex Relationships and Beyond: Gender Matters in the EU (Intersentia, 2017).

22 M. M. Winkler (above n. 12) 390-393.

23 For a piece on surrogacy (in general) and the main objections towards it see K. Orfali, 'The Contested Terrain of Surrogate Motherhood' in B. Feuillet-Liger, T. Callus and K. Orfali (eds), Reproductive Technology and Changing Perceptions of Parenthood around the world (Bruylant, 2014).

24 Austria, Belgium, Denmark, Finland, Ireland, Luxembourg, Malta, Netherlands, Portugal, Spain, Sweden, and the UK.

25 Austria, Belgium, Denmark, Finland, Ireland, Malta, Netherlands, Portugal, Spain, and the UK. 
All in all, in a little less than half of the EU Member States (namely, twelve Member States) same-sex couples are unable to be recognised (legally) as co-parents. ${ }^{26}$

Accordingly, it is clear that in EU Member States, there is currently a legal patchwork regarding the legal recognition of the parental status of same-sex couples, this reflecting how controversial the matter is. ${ }^{27}$ In fact, rainbow parenting is considered to be the most controversial issue in relation to the legal recognition of same-sex relationships and its prohibition is often used as the strongest card by governments wishing to pass legislation offering a legal status to same-sex couples: in exchange of securing approval for legislation which legally recognises same-sex couples, governments promise that they will not provide parenting rights to such couples. ${ }^{28}$

The concept of 'family', therefore, differs from Member State to Member State, and only some EU Member States fully recognise rainbow families under the law by allowing the couple's intent to override the biological relationship between the child and one or both of his/her parents. In most EU Member States, a child born to a samesex couple has only one legal parent, which means that the other parent of the child is not afforded any legal recognition as a parent. Thus, in a number of EU Member States, rainbow families are rendered invisible within society and its legal structures and cannot legally establish the familial links among (all) their members. As Hodson has aptly put it, '[t] he extent to which a child's family is recognised in Europe is, at present, a haphazard accident of geography'. ${ }^{29}$

This is clearly problematic as, apart from the emotional significance that the recognition of a child as the child of both of his/her parents has, being considered the child of one's parents is important from a practical and legal perspective as well, since it is only in this way that parents can fulfil their obligations to their child and the child can claim rights as their child. ${ }^{30}$ For instance, it is only (legal) parents that benefit from

26 These are Bulgaria, Cyprus, Czech Republic, Estonia, Greece, Hungary, Italy, Latvia, Lithuania, Poland, Romania, Slovakia.

27 See P. Dunne, 'Who is a Parent and Who is a Child in a Same-Sex Family? - Legislative and Judicial Issues for LGBT Families Post-Separation, Part I: The European Perspective', (2017) 30 Journal of the American Academy of Matrimonial Lawyers 27, 31 (and the references in footnote 13 of that article). Hodson has, also, noted that although the ECtHR now recognises de facto families as valid families that are entitled to the protection of their rights, nonetheless, at present it 'provides too little guidance on matters of family rights and equality for children raised in LGBT families' and 'in short, the ECtHR has failed to grapple adequately with the dynamics of LGBT family life' - L. Hodson (above n. 7) 519. For a historical analysis of the law in the US as regards parenting by same-sex couples see N. D. Polikoff, 'Lesbian and Gay Couples Raising Children: The Law in the United States' in R. Wintemute and M. Andenas (eds), Legal Recognition of Same-Sex Partnerships: A Study of National, European and International Law (Hart, 2001).

28 See, for instance, the discussions in Cyprus, France, Italy, and Greece, where as a political compromise deemed necessary to convince the more traditional sections of the legislature to accept the introduction of legal recognition of same-sex couples, co-parenting by same-sex couples (or, in the case of France, some forms of co-parenting) was left out or subsequently removed from the proposed legislation.

29 L. Hodson (above n. 7) 520.

30 A. Koppelman, Same Sex Different States: When Same-Sex Marriages Cross State Lines (Sheridan, 2006) 73-74. 
administrative privileges in relation to the child (such as the capacity to consent to medical care and open a bank account for the child), travel alone with the child, or provide health insurance for the child. In addition, in systems where an ius sanguinis approach is adopted, children can only acquire the nationality of a country from persons who are recognised, in law, as their parents. If the parent who is not legally recognised as their parent dies intestate, his/her children will not be entitled to inherit his or her property. Moreover, if it is the legal parent that dies, the child becomes an orphan and it is then up to the family of the legally recognised parent or, in the absence of that, the State, to determine if the non-recognised parent will be allowed to, even, maintain links with the child and, ideally, be recognised as the child's parent. The child, also, does not have any (legal) ties with the family of origin of the parent who is not legally recognised as a parent. ${ }^{31}$

The above list is not exhaustive, ${ }^{32}$ but it paints a picture of the kinds of struggles samesex couples and their children may suffer as a result of the failure of the law to recognise their familial ties. The failure to legally recognise the parent-child relationship creates uncertainty and, with it, insecurity both for the parents and the child as it, in effect, denies their relationship. It can, also, cause bureaucratic complications and unnecessary delays. One should, also, not ignore the psychological consequences that this can have both for the parents and the child, not least as a result of the stigma to which rainbow families are commonly exposed. As has been noted by another commentator, 'the legal invisibility of same-sex parents in nations around the world leaves them vulnerable to the loss of their rights as a family unit and requires partners, parents and children to engage in additional relational work to feel socially legitimated as a family'.33

This brief section aimed to provide the reader with some background information regarding the regulation of parenting by same-sex couples in individual EU Member States and to expose the difficulties that rainbow families face at national level. This article, nonetheless, is not concerned with the question whether EU Member States are required by EU law to make it possible for same-sex couples to become the joint parents of a child in their territory and to be legally recognised as such under their own legal system: in other words, the article's aim is not to examine whether EU law requires Member States to introduce legislation which enables rainbow families in their territory to legally establish familial ties among their members ab initio. This is a matter - after all - which, as will be explained below, falls outside EU competence and, thus, from the point of view of EU law, Member States can adopt towards it the approach that is most appropriate within their own socio-political context. What this

31 For the importance of legally recognising a child's ties with their parents' families of origin see Marckx v. Belgium, no. 6833/74, 1979, paras 44-48.

32 For a more detailed analysis of the problems faced by rainbow families as a result of the nonrecognition of the parental ties between a child and (usually) his/her non-biological parent see L. Hodson, 'The Rights of Children raised in lesbian, gay, bisexual or transgender families: A European perspective', ILGA-Europe 2008 <https://www.ilga-europe.org/resources/ilgaeurope-reports-and-other-materials/rights-children-raised-lesbian-gay-bisexual-or> pp. 29-32 (accessed on 17.12.2018).

33 R. Wilding, Families, Intimacy and Globalization (Palgrave, 2018) 6. 
article aims to explore is, rather, whether EU law can require Member States, in situations where there is an exercise of free movement rights by rainbow families, to legally recognise the familial links between the children and both of their parents, as these have already been legally established elsewhere (i.e. in countries which have legislation which permits rainbow families to legally establish such links). The remaining of this article, therefore, is devoted to this question.

\section{Free Movement And Family Reunification Under EU Law: The Position of Children}

EU law grants to all EU citizens the right to move and reside freely in the territory of another Member State. The right derives from the free movement of persons provisions of the Treaty on the Functioning of the European Union (TFEU), ${ }^{34}$ which prohibit obstacles to the exercise of this right. These provisions also grant a number of additional rights to Member State nationals, most notably, the right not to be discriminated against on the ground of nationality. ${ }^{35}$

Yet, the free movement of persons provisions have never made reference to the family of the migrant Union citizen. However, being aware of the importance of family life for all human beings and - more pragmatically - of the fact that Union citizens would be impeded from moving if the host State refused to admit their close family members within its territory, since the 1960s, the secondary legislation complementing the free movement of persons provisions grants family reunification rights to Union citizens who move between Member States. ${ }^{36}$

Currently, the main source of such rights is Directive 2004/38. ${ }^{37}$ The Directive applies only to 'Union citizens who move to or reside in a Member State other than that of which they are a national'. ${ }^{38}$ However, the European Court of Justice (ECJ) has extended its application 'by analogy' to Union citizens who return to their Member State of nationality after having spent a period of 'genuine residence' in the territory

34 The right is now laid down in Article 21 TFEU and - the leges speciales to it - Articles 45, 49, and 56 TFEU.

35 See, e.g. Case 167/73, Commission v. France EU:C:1974:35. Article 21 TFEU does not explicitly prohibit discrimination on the ground of nationality and, thus, in case-law, it has been applied together with Article 18 TFEU in order to prohibit discrimination on this ground.

36 Case 249/86 Commission v. Germany EU:C:1989:204, para. 11. For an analysis of family reunification rights under EU free movement law see C. Berneri, Family Reunification in the EU: The Movement and Residence of Third Country National Family Members of EU Citizens (Hart, 2017).

37 Council and Parliament Directive 2004/38 on the right of citizens of the Union and their family members to move and reside freely within the territory of the Member States [2004] OJ L $158 / 77$.

$38 \quad$ Ibid., Article 3. Emphasis added. 
of another Member State, during which they established and strengthened family life. ${ }^{39}$

Directive 2004/38 grants to Union citizens the automatic right to be joined or accompanied by their 'family members' in the territory of the Member State to which they move, i.e. the host State is required by EU law to admit the family members within its territory without applying its own immigration requirements, and this is so irrespective of whether the family member is a Union citizen or not. ${ }^{40}$ It should be underlined that family reunification rights - as rights which follow from the EU right to free movement - are directly granted by EU law only to Union citizens who exercise their right to move and reside in the territory of another Member State. Family members, therefore, enjoy family reunification rights only as a result of their relationship with the Union citizen and, thus, their rights are derivative. Of course, family members who hold Union citizenship enjoy free movement rights on their own right and, thus, in most instances, do not need to claim (derivative) rights which emerge as a result of their relationship with the Union citizen who decides to move. However, in the context of rainbow families, the applicability of EU law is also practically significant in situations where (derivative) family reunification rights are claimed by family members who do possess Union citizenship, as for them it will be important to be legally recognised as the 'family members' of the Union citizen, especially in Member States which do not recognise them as such under their national laws.

In order for family reunification rights to be meaningful, they need to be supplemented by a number of additional (related) rights which have as their aim to ensure that the family can become integrated into the society of the host Member State. Accordingly, provision for this is made in Directive 2004/38 and other pieces of secondary legislation which supplement the free movement of persons provisions. ${ }^{41}$ This means that whether the family members qualify as a 'family' for the purposes of the grant of EU family reunification rights, will not only determine if they will all be able to be admitted into - and granted a right to reside in - the territory of the host Member State, but will also determine if they will be able to benefit from a host of other rights, ${ }^{42}$ such as the right for the family members to work in the host Member

39 Case C-370/90, Singh EU:C:1992:296; Case C-456/12, O. and B. EU:C:2014:135; Case C-673/16, Coman EU:C:2018:385.

40 Recital 5, Directive 2004/38 (above n. 37). It is throughout its text that the Directive makes it clear that the family members of Union citizens can accompany or join them in the host Member State and, hence, reference will not be made to specific Articles of the Directive from which family reunification rights are derived.

41 See, especially, Regulation 492/2011 on freedom of movement for workers within the Union [2011] OJ L 141/1.

42 C. Berneri (above n. 36) 1 (footnote 2). 
State ${ }^{43}$ and the right for the children of the family to receive study finance in the host State under the same conditions as this is granted to the nationals of that State. ${ }^{44}$

For the purposes of Directive 2004/38, 'family members' are defined in Article 2(2) as: '(a) the spouse;

(b) the partner with whom the Union citizen has contracted a registered partnership, on the basis of the legislation of a Member State, if the legislation of the host Member State treats registered partnerships as equivalent to marriage and in accordance with the conditions laid down in the relevant legislation of the host member State;

(c) the direct descendants who are under the age of 21 or are dependants and those of the spouse or partner as defined in point (b); and

d) the dependent direct relatives in the ascending line and those of the spouse or partner as defined in point (b).'

For family members that do not fall within the above list, Article 3(2) of the Directive provides:

'Without prejudice to any rights to free movement and residence the persons concerned may have in their own right, the host Member State shall, in accordance with its national legislation, facilitate entry and residence for the following persons:

(a) any other family members, irrespective of their nationality, not falling under the definition in point 2 of Article 2 who, in the country from which they have come, are dependants or members of the household of the Union citizen having the primary right of residence, or where serious health grounds strictly require the personal care of the family member by the Union citizen;

(b) the partner with whom the Union citizen has a durable relationship duly attested.'

Persons that only fall within the Art. 3(2) categories, cannot require the host State to automatically accept them within its territory but can only require it to justify its decision in case it chooses not to admit them - to do so, it will need to demonstrate that it has undertaken an extensive examination of their personal circumstances. ${ }^{45}$

It should be noted that all Union citizens - including children - can exercise free movement rights and claim family reunification rights under EU law. As the ECJ has confirmed, '[t]he capacity of a national of a Member State to be the holder of rights guaranteed by the Treaty and by secondary law on the free movement of persons cannot be made conditional upon attainment by the person concerned of the age prescribed for the acquisition of legal capacity to exercise those rights personally' ${ }^{46}$

$43 \quad$ Directive 2004/38 (above n. 37), Article 23.

44 Article 10 Regulation 492/2011 (above n. 41) and Joined Cases C-389-390/87, Echternach and Moritz EU:C:1989:130.

45 Case C-83/11, Rahman EU:C:2012/519.

Case C-200/02, Zhu and Chen EU:C:2004:639, para. 20. See C. Sawyer, 'Civis Europeanus sum: the citizenship rights of the children of foreign parents' (2005) Public Law 477; A. Tryfonidou, 'Kunqian Catherine Zhu and Man Lavette Chen v. Secretary of State for the Home Department: Further Cracks in the "Great Wall" of the European Union?' (2005) 11 European Public Law 527. 
Given that the article shall focus on the position of the children of rainbow families, I shall here confine myself to summarising the four ways in which children (in general) can benefit from family reunification rights under EU free movement law.

First, a child can fall under the Article 2(2)(c) category of Directive 2004/38, when (s)he is the 'direct descendant' of a Union citizen who exercises free movement rights or of the spouse or registered partner of that Union citizen. ${ }^{47}$ The child can fall within this category irrespective of whether (s)he is a Union citizen, but (s)he can only be covered if under the age of 21 or a dependant of his/her parent(s).

Secondly, under the Article 2(2)(d) category of the Directive, if the child is a Union citizen and is not dependent on his/her parent(s), (s)he can act as the 'sponsor' of family reunification (and related) rights for his/her parent(s), if the latter are not EU citizens and thus do not enjoy free movement rights themselves.

Thirdly, in Zhu and Chen, ${ }^{48}$ the Court held that minors who are Union citizens and wish to exercise their right to move and reside in the territory of another Member State in their own right, can claim the right to be joined or accompanied by their primary carer in the host State, provided that the family is economically self-sufficient. ${ }^{49}$ This right is derived directly from Article 21 TFEU. Prior to this, in Baumbast, it was held that the children (whether they are EU citizens or not, and whether they are minors or not) of a 'worker' (within the meaning of Article 45 TFEU) who have moved to the host Member State with him and have exercised their derivative right to enrol in full-time education there, can themselves 'sponsor' a right of residence for their primary carer (irrespective of whether the primary carer is an EU citizen or not), if they need the presence and the care of that person in order to be able to continue to pursue and complete their education in that Member State..$^{50}$ It should be noted, however, that

In the recent Coman case (above n. 39), the ECJ interpreted the term 'spouse' for the purposes of Article 2 of Directive 2004/38, to include the same-sex spouse of a Union citizen who moves and resides in the territory of another Member State. Accordingly, when the parents of a child in a rainbow family are married, the host Member State should recognise them as such, and, hence, even if the host Member State refuses to legally recognise the child as the child of one of his/her parents, if the parent who is not legally recognised as such is the Union citizen, the child can still derive family reunification rights from that parent, as it is considered as the child of the Union citizen's spouse. The ECJ has not yet had the opportunity to clarify the meaning of 'registered partner' and, in particular, to rule on whether it includes same-sex registered partners. For an analysis of Coman see, inter alia, D. Kochenov and U. Belavusau (above n. 3); A. Tryfonidou, 'The ECJ Recognises the Right of Same-Sex Spouses to Move Freely between EU Member States: The Coman Ruling' (2019) European Law Review (forthcoming).

(above n. 46), paras 26-34.

49 It should be noted that given that the article is about the free movement rights of rainbow families, the possibility of employing the principle established in Case C-34/09, Ruiz Zambrano EU:C:2011:124, which enables children who are Union citizens to continue to reside in the territory of the Member State of their nationality with their primary carer, will not be considered here.

50 Case C-413/99, Baumbast and R EU:C:2002:493, paras 68-75. This right is derived from (what is now) Article 10 of Regulation 492/2011 (above n. 41). See, also, Case C-310/08, Ibrahim EU:C:2010:80; Case C-480/08, Teixeira EU:C:2010:83; Case C-529/11, Alarape EU:C:2013:290; and Articles 12 and 13 of Directive 2004/38 (above n. 38). For an analysis of the principles 
this is so only where one of the parents of the children is a 'worker' (and - thus applies in a narrower set of circumstances than the Zhu and Chen principle does), and in this context it is not necessary that the family is economically self-sufficient.

Finally, if a child does not fall within any of the above categories, (s)he can try to rely on Article 3(2)(a) of Directive 2004/38, as a dependant or member of the household of the Union citizen. Alternatively, if the child is a Union citizen, (s)he can be the sponsor of (non-automatic) family reunification rights, if the persons that wish to join the child can prove that they are members of the child's household in the home Member State or are dependent on the child. ${ }^{51}$ But as seen earlier, in both these cases, the decision whether to admit the family members falls entirely within the discretion of the host Member State and a decision to admit them under this category does not presuppose recognition of their familial ties.

Children who come from a traditional, nuclear, family can, clearly, qualify as 'direct descendants' - and their parents as 'direct relatives in the ascending line' or as 'primary carers' - for the purposes of the above categories; there has never been a case where the familial links between children and their biological parents have been legally questioned in this context. In addition, certain non-traditional families are, also, covered by the Directive; for instance, Article 2(2)(c) of the Directive recognises the link between children and their (heterosexual) step-parents, as it explicitly provides that a Union citizen has the right to be joined in the host State by, inter alia, the children of his/her spouse or registered partner. Those families whose members fall within the above categories can, therefore, feel certain that their decision to exercise EU free movement rights, will not give rise to a separation of the members of the family as all will have the right - deriving from EU law - to be admitted to the territory of the host Member State and to be allowed to reside there. What is more, they are aware that they will be entitled to claim all rights reserved for families, once they are admitted into the territory of the host Member State, since they will be recognised as a 'family'.

The important question for our purposes, nonetheless, is whether the term 'family' for the purposes of EU free movement law - includes rainbow families. In particular, the question that will be explored in the next section will be whether the categories of family members enumerated in Directive 2004/38 cater for the children of rainbow families by recognising their relationship with (both of) their parents, as this has been lawfully established in a legal system which permits same-sex couples to jointly parent a child.

established in the cases mentioned in this paragraph see H. Stalford, Children and the European Union: Rights, Welfare and Accountability (Hart, 2012) 72-78.

51 If the child is a minor it is unlikely that a relationship of dependency satisfying the requirements of this provision (i.e. the parent being (materially) dependent on the child) will be found - see Zhu and Chen (above n. 46), paras 43-44; Case C-40/11, lida EU:C:2012:691, paras 54-56. 


\section{Rainbow Families and EU Free Movement Law: The Current (Unclear) Position}

As we saw in section II, currently, only a handful of EU Member States fully recognise rainbow families in their legal systems. Accordingly, when exercising free movement rights deriving from EU law, rainbow families may end up in legal limbo: if the Member State to which they move does not allow same-sex couples in its territory to become co-parents, it is likely that it will refuse to recognise, also, the parent-child relationship between a child and one or, sometimes, even both of his/her same-sex parents, as this has been legally established elsewhere. Thus, when rainbow families move between EU Member States, the children may face losing legal ties to one or both of their parents, something which will undoubtedly lead them to grow up in fear and uncertainty as well as suffer a number of legal and other practical disadvantages, such as those we saw earlier in section II, when considering non-recognition of rainbow families in a single-country context.

As regards family reunification (and related) rights, as seen in the previous section, the applicable EU legislation - Directive 2004/38 - simply speaks about 'direct descendants' and 'relatives in the ascending line', without interpreting these terms in more detail. Moreover, there is no established EU definition for the words 'parent', 'primary carer', or 'child', ${ }^{2}$ which means that it is not clear if, for the purposes of EU law, the relationship between a child and both of his/her same-sex parents is recognised and, in particular, whether EU law legally recognises the non-biological parent as a 'parent'. McGlynn has stressed that the requirement in the 2004 Directive that the children be the 'direct descendants' of the Union citizen (or his/her spouse or registered partner) 'does, unfortunately, raise a question regarding adopted children or those born using fertility treatments where the child cannot be said to be a direct "descendant"'. ${ }^{53}$ On the other hand, Stalford appears more optimistic and argues that the reference in the same Directive to the 'direct descendants' of the EU citizen or his/her spouse or partner seems to imply that 'children with no direct biological link to EU migrant adults (the primary beneficiaries of free movement entitlement) can now benefit from the panoply of entitlement previously restricted to their biological children' and considers that it includes step-children, adopted or foster children, or even the children of the migrant's unmarried partner. ${ }^{54}$ This seems to be the view, also, espoused by the ECJ as from its case-law to date we know that a biological link between a child and the Union citizen from whom the family reunification rights are derived, is not required. ${ }^{55}$ The Court, in particular, has made clear that the stepchildren of the Union citizen who exercises free movement, can join or accompany him or her in the host Member State and can enjoy a number of additional rights, such as the right to have access to education in the host State under the same terms as this

52

See para. 7 of the Opinion of AG Tesauro in Case C-7/94 Gaal EU:C:1995:29. See, also, H. Stalford (above n. 50) 21.

53

C. McGlynn (above n. 10) 48.

H. Stalford (above n. 50) 24.

See H. Stalford (above n. 50) 23-24; F. Emmert, 'The Family Policy of the European Community' in K. Waaldijk and A. Clapham (eds), Homosexuality: A European Community Issue (Martinus Nijhoff, 1993) 370. 
is available to nationals of that State. ${ }^{56}$ Moreover, children who are Union citizens can 'sponsor' the right of residence of a third-country national primary carer who is not genetically linked to them. ${ }^{57}$

Nonetheless, to date, no case has been referred to the ECJ involving the free movement rights of rainbow families and, hence, the Court has not been given the opportunity to rule on the matter. Accordingly, although it seems that the absence of a biological connection between a child and his/her parent does not, in itself, negate the parent-child relationship for the purposes of EU law, it is not clear if this is the case, also, in situations where that parent is in a same-sex relationship with the child's other parent. The lack of clarity in the terms used in the 2004 Directive and the judgemade category of 'primary carer', and the absence of any clarification offered by the $E C J$ as regards the children of rainbow families in particular, has given cause to Member States which do not make provision for such families within their own legal system, to believe that they are free to refuse to recognise the familial links between the members of such families when they move to their territory in exercise of EU free movement rights. ${ }^{58}$ Accordingly, when rainbow families move, the legal ties binding their members are put in jeopardy.

In some cases, the legal ties between a child and both of his/her parents will dissolve when the family moves to another Member State. For instance, prior to the change of the law in Portugal in 2016, in one case the Portuguese authorities refused to recognise the parental ties between a child and both of the adoptive same-sex parents

$56 \quad$ Baumbast (above n. 50), para. 57.

57 Joined Cases C-356-357/11, O, S and L EU:C:2012:776, para. 55. On the facts of the case, this right was derived from Article 20 TFEU, as the case did not involve the exercise of free movement rights, but it is unlikely that the Court will adopt a different position in situations involving the exercise of free movement under Article 21 TFEU or the other free movement of persons provisions.

58 The recent Regulation 2016/1191 on promoting the free movement of citizens by simplifying the requirements for presenting certain public documents in the European Union and amending Regulation 1024/2012 [2016] OJ L200/1, does not provide much assistance to rainbow families as it merely concerns the authenticity of the document, not the recognition of its content. The same is the case for Council Regulation 2201/2003 concerning jurisdiction and the recognition and enforcement of judgments in matrimonial matters and the matters of parental responsibility, repealing Regulation 1347/2000 (Brussels IIA) (2003) OJ L338/29, which provides that where a court order as to parental authority has been made in another EU Member State (other than Denmark) in respect of a child, and the court has jurisdiction in the matter, that court order must be recognised in other EU Member States without any special procedure being required. Rainbow families are unlikely to benefit from this piece of legislation either as, on the one hand, adoption is excluded from the Regulation's scope and, on the other hand, it provides for an exception where recognition would be 'manifestly contrary to the public policy of the Member State in which recognition is sought', which would most probably be relied on by Member States that refuse to legally recognise the parent-child relationship between a child in a rainbow family and one (or both) of his/her parents. In addition, the Regulation expressly excludes establishing or contesting the parent-child relationship. For more on Brussels IIA see N. Lowe and G. Douglas, Bromley's Family Law (OUP, 2015) 994-1008. 
- as these were established in Belgium via an adoption order - because Portuguese law at the time did not allow adoptions by same-sex couples. ${ }^{59}$

In other cases, it is only the legal links between the child and one of her parents (the non-birth mother or the non-biological parent) that are not recognised, when the family moves to another Member State. This is demonstrated by a petition recently made to the Committee of Petitions (PETI) of the European Parliament, by Eleni Maravelia, a Greek national who is married to a British woman. ${ }^{60} \mathrm{Ms}$ Maravelia gave birth to a daughter in Spain in 2014. The Spanish birth certificate of the daughter of the couple indicates both Ms Maravelia and her spouse as parents of the child. Yet, in Greece - which does not legally recognise same-sex couples as co-parents - they were told that only the birth mother is recognised as the parent of the child, this making Ms Maravelia the sole parent of the child for the purposes of Greek law.

Of course, it should be noted that not all Member States which do not allow same-sex parents in their territory to legally establish ties with their children refuse to recognise, also, the legal ties established between a child and his/her parents elsewhere. For instance, in Italy a number of cases have been heard in recent years, and courts have ruled that second-parent adoption orders issued in another Member State should be recognised by the Italian civil registrars and that the latter must recognise the birth certificate of a child by another Member State which indicated that two women were the child's parents. ${ }^{61}$ Similarly, very recently, the Supreme Administrative Court of Poland allowed both of the mothers of a child - as reflected in a British birth certificate - to be legally recognised as such in Poland. ${ }^{62}$

59 Report on Round Table on Rainbow Families (above n. 7) p. 3. For additional examples of the non-recognition of the legal ties between a child and both of his/her same-sex parents, as these have been established elsewhere, see M. M. Winkler (above n. 12) 388-389.

60 Petition No $0513 / 2016$ by Eleni Maravelia (Greek) on the non-recognition of LGBT families in the European Union https://petiport.secure.europarl.europa.eu/petitions/en/petition/content/0513\%252F2016/ht ml/Petition-No-0513\%252F2016-by-Eleni-Maravelia-\%2528Greek\%2529-on-the-non-

recognition-of-LGBT-families-in-the-European-Union> (accessed on 22.06.2018). For additional examples see NELFA Public Petition to EU Commissioner Viviane Reding 'Same-Sex Parents and their Children demand True Freedom of Movement in the European Union' (24.09.2013) $<$ http://Igbt-families.eu/wp-

content/uploads/2013/05/NELFAPetitiontoCommissionerRedingFINAL.pdf> (accessed on 17.01.2019); and NELFA 'Freedom of Movement in the European Union: Obstacles, Cases, Lawsuits ...' (January 2019) http://nelfa.org/inprogress/wp-content/uploads/2019/01/NELFAfomcasesdoc-2019-1.pdf (accessed on 21.01.2019).

61 ILGA Europe Annual Review 2018, available at < $\underline{\text { https://www.ilga- }}$ europe.org/sites/default/files/Attachments/annual review final2018 web.pdf> p. 78 (accessed on 20.12.2018). See, also, footnotes 65 and 66 in S. Marinai, 'Recognition in Italy of same-sex marriages celebrated abroad: The importance of a bottom-up approach' (2016) 9 European Journal of Legal Studies 10, for references to such cases.

62 See 'Gay couple can register child in conservative Poland - court', Reuters, 11 October 2018 $<$ https://uk.reuters.com/article/uk-poland-gayrights/gay-couple-can-register-child-inconservative-poland-court-idUKKCN1ML1PC> (accessed on 15.10.2018). 
In any event, research has shown that once the parents are admitted to their territory, host States tend to facilitate the entry and residence also of the children of a rainbow family, as per the Article 3(2)(a) category of Directive 2004/38, even if their laws do not recognise them as the children of their parents. ${ }^{63}$ In other words, the Article 3(2)(a) category achieves the perfect compromise for Member States which do not allow same-sex parenting in their territory, as it does not make reference to familial links but merely speaks about 'dependants' or 'members of the household' of a Union citizen - thus, it does not presuppose the recognition of the actual familial links between the child and both of his same-sex parents, which is, exactly, what the host Member State usually wishes to avoid.

Hence, in most cases, the main issue appears to be not so much whether rainbow families will be able to move to another Member State (i.e. an 'access' issue) but, rather, how they will be able to move: once admitted within the territory of the host State, will they be recognised as a 'family' for all legal purposes, with the legal ties connecting the parents and their child(ren) remaining intact?

Research on the cross-border legal recognition of rainbow families and the legal status attached to their members has 'revealed a chaotic mosaic of full, partial, unclear, and denied recognitions'. ${ }^{64}$ The non-recognition of the legal ties between a child and one or both of his/her parents demonstrates that some EU Member States insist on failing to recognise the social realities of the familial relationships of the children of rainbow families, in this way jeopardising their legal security. And this is so even if the children and their parents do enjoy in another country the security of having their ties legally recognised. As another commentator has pointed out when writing on this topic in the US context, 'these children can have their entire life turned upside down by simply crossing a state border' ${ }^{65}$

The next section will, therefore, be devoted to an analysis of the ways in which the failure of the host EU Member State to recognise the legal ties (as these have been established elsewhere) between a child and both of his/her parents, can breach a number of rights that the child enjoys under EU law.

V Is the Refusal of the Host Member State to Recognise the Legal Ties Among the Members of a Rainbow Family that Moves to its Territory a Breach of EU Law?

Traditionally, opposite-sex married spouses and their (biological) children have constituted the only recognised form of 'family' for legal purposes. This had been the

63 Cara-Friend Northern Ireland, 'Handbook on the Rights of Rainbow Families: Rights on the move' (2014), p. 28, <https://www.ilga-europe.org/sites/default/files/rights on the move handbook on the rights of rainbow families 2015.pdf> (accessed on 10.05.2018).

64

K. Waaldijk, 'The Right to Relate: A Lecture on the Importance of Orientation in Comparative Sexual Orientation Law' (2013) 24 Duke Journal of Comparative and International Law 161, 198.

65 L. S. Anderson, 'Protecting Parent-Child Relationships: Determining Parental Rights of Same-Sex Parents Consistently Despite Varying Recognition of their Relationship' (2006) 5 Pierce Law Review 1, 2. 
approach not merely of individual EU Member States but, also, of the EU itself. ${ }^{66}$ Such an approach ignored the existence of (inter alia) rainbow families. Nonetheless, the sands have started shifting, albeit slowly, and a number of (western) EU Member States now view and recognise rainbow families as legitimate families that must have equal protection under the law. But has there been a change, also, in the EU's approach?

The European Parliament - the most pro-LGB among the EU institutions - has repeatedly made calls to the other institutions, to create a legal framework at EU level which, whilst it respects the competence of the Member States in the family law field, it recognises and protects the rights of rainbow families who make use of EU free movement rights.

For instance, back in 1994 - at a time when only one EU Member States (Denmark) offered some form of legal recognition to same-sex relationships - the Parliament had issued a Resolution, noting, inter alia, that the Commission should draft a Recommendation on equal rights for lesbians and homosexuals, which would, as a minimum, seek to end 'the barring of lesbians and homosexual couples from marriage or from an equivalent legal framework, and should guarantee the full rights and benefits of marriage, allowing the registration of partnerships' as well as 'any restrictions on the rights of lesbians and homosexuals to be parents or to adopt or foster children'. ${ }^{67}$ Moreover, in its recent Resolution on protection and nondiscrimination with regard to minorities in the EU Member States, ${ }^{68}$ the Parliament, inter alia, recommended the provision of clear and accessible information on the recognition of cross-border rights for LGBTI persons and their families in the $\mathrm{EU}^{69}$ and urged the Commission to ensure that Member States correctly implement Directive 2004/38, consistently respecting, inter alia, the provisions related to family members and prohibiting discrimination on any grounds. ${ }^{70}$ In the same Resolution, the Parliament called on the Commission to take action in order to ensure that LGBTI individuals and their families can exercise their right to free movement in accordance with both Article 21 TFEU and Article 21 EUCFR. ${ }^{71}$

66 H. Stalford, 'Concepts of Family under EU Law - Lessons from the ECHR' (2002) 16 International Journal of Law, Policy and the Family 410; C. McGlynn (above n. 10).

67 European Parliament Resolution on equal rights for homosexuals and lesbians in the EC A30028/94 (1994) OJ C 61/40.

68 Resolution on protection and non-discrimination with regard to minorities in the EU Member States 2017/2937(RSP), available at $<$ http://www.europarl.europa.eu/sides/getDoc.do?pubRef=\%2f\%2fEP\%2f\%2fTEXT\%2bMOTION\%2bB8-20180064\%2b0\%2bDOC\%2bXML\%2bV0\%2f\%2fEN\&language=EN> (accessed on 25.06.2018). This motion was, in fact, the European Parliament's response to the PETI public hearing organised by the Committee on Petitions (PETI) entitled 'Fighting against discrimination of EU citizens in the EU Member States and the protection of minorities' that took place on 4 May 2017, where the Petition submitted by Eleni Maravelia (above n.60) was heard.

69 Resolution on protection and non-discrimination with regard to minorities in the EU Member States (above n. 68) para. 19.

70 Ibid., para. 20.

71 Ibid., para. 21. 
Yet, despite the Parliament's repeated calls for a legal framework which caters for the needs of rainbow families and which grants them equal protection and equal rights to those enjoyed by the traditional nuclear family, the EU has, to date, buried its head in the sand in relation to this matter. The other EU institutions have chosen to ignore social reality, with the result that rainbow families live in a state of legal uncertainty: a mere attempt to exercise the core - free movement - rights they enjoy under EU law, often brings them face to face with the harsh reality that their family is not recognised in many EU Member States.

Member States which refuse to recognise the legal status attached to familial relationships legally established elsewhere will, usually, claim that this is required by national law or by public policy principles, and that private international law rules allow them the freedom to do so. However, as noted by Biagioni, 'in several occasions it has been argued that the application of private international law rules cannot lead to interferences with a status established under a foreign law, insofar as the creation of a limping status can result into a violation of fundamental rights' ${ }^{72}$

Accordingly, the question that this section shall aim to answer is whether the refusal of the host Member State to legally recognise the familial ties among the members of a rainbow family - as these have been established and recognised elsewhere breaches fundamental rights protected under EU law. The section will, therefore, focus on whether the EU has the competence and the tools to require its Member States to legally recognise the familial links between the members of rainbow families in situations where such families move between Member States.

\section{V.1 DOES THE EU HAVE THE COMPETENCE TO ACT?}

As is well-known - and as has been repeatedly confirmed by the ECJ ${ }^{73}$ - family law is an area that still broadly falls within the regulatory purview of Member State competence. Thus, the EU does not have competence in the family law field but, merely, a limited power to adopt harmonising measures on family law with crossborder implications. ${ }^{74}$ It has, therefore, been left to the Member States to decide what legal recognition, if any, will be given to same-sex couples in their territory. ${ }^{75}$ Similarly,

72 G. Biagioni, 'On Recognition of Foreign Same-Sex Marriages and Partnerships' in D. Gallo, L. Paladini and P. Pustorino (eds), Same-Sex Couples Before National, Supranational and International Jurisdictions (Springer 2014) 360-361.

73 Case C-267/06, Maruko EU:2008:179, para. 59 ; Case C-443/15, Parris EU:C:2016:897, para. 59; Coman (above n. 39), para. 37.

74 Article 81(3) TFEU - such measures require the unanimous approval of the Council of the EU. $\mathrm{H}$. Stalford, 'For Better, For Worse: The Relationship between EU Citizenship and the Development of Cross-border Family Law' in M. Dougan, N. Nic Shuibhne and E. Spaventa (eds), Empowerment and Disempowerment of the European Citizen (Hart, 2012).

75 This is also the approach adopted by the ECtHR when interpreting the ECHR, in view of a lack of European consensus on the matter among the signatory states - see, for instance, Schalk and Kopf v. Austria, no. 30141/04, 2010, para. 61, X and Others v. Austria (above n. 7) para. 106, and Chapin and Charpentier v. France, no. 40183/07, 2016, paras 38-39 and 48. For comments see N. Bamforth, 'Families but not (yet) marriages? Same-sex partners and the development 
it is left to EU Member States to decide whether they will allow same-sex couples in their territory to become de facto parents and to establish a family under the law. ${ }^{76}$ This deference to Member State choices with regards to these matters is, also, reflected in the text of the human rights instruments of both the Council of Europe (of which all EU Member States are members) and of the EU: Article 12 of the European Convention on Human Rights (ECHR) provides the right to marry and to found a family 'according to the national laws governing the exercise of this right', whilst Article 9 of the EU Charter of Fundamental Rights (EUCFR) notes that the same right 'shall be guaranteed in accordance with the national laws governing the exercise of these rights'.

Yet, even when they act in areas that fall within their exclusive competence, Member States must act in a way which respects their obligations under EU law. ${ }^{77}$

Among these, is the obligation to respect the right to free movement of Union citizens, which is considered one of the fundamental rights deriving from EU law. In particular, in situations which fall within the scope of EU law by virtue of the (mere) exercise of free movement rights by a Union citizen, Member States must comply with their obligations under the EU free movement provisions and the secondary legislation complementing them. As explained elsewhere, the ECJ has made it clear in a number of cases that in order for a situation to fall within the scope of the free movement of persons provisions, it suffices that a Union citizen has exercised free movement rights; it is not, in addition, necessary to prove that on the facts of the case, there is an interference with the exercise of those rights. ${ }^{78}$

European Convention "margin of appreciation"” (2011) 23 Child and Family Law Quarterly 128; H. Fenwick, 'Same sex unions at the Strasbourg Court in a divided Europe: driving forward reform or protecting the court's authority via consensus analysis?' (2016) European Human Rights Law Review 248. However, if domestic law creates a family status other than marriage (e.g. registered partnership) it must do so without discrimination on the ground of sexual orientation, meaning that it must be open to both same-sex and opposite-sex couples (see, e.g. Vallianatos v. Greece, no. 29381/09, 2013) - see M. Fichera, 'Same-Marriage and the Role of Transnational Law: Changes in the European Landscape' (2016) 17 German Law Journal 383, 397. However, see, also, Oliari v. Italy, no. 18766/11 and 36030/11, 2015, which seems to have created an obligation for ECHR signatory States to provide a legal framework for the recognition of samesex relationships, though it may be that the ECtHR has imposed this obligation specifically on Italy (the State concerned) because legal and political factors particular to Italy were taken into account by the ECtHR when establishing this. For a discussion see A. Hayward, 'Same-Sex Registered Partnerships - A Right to Be Recognized?' (2016) 75 Cambridge Law Journal 27.

This is also the approach adopted by the ECtHR when interpreting the ECHR - see, for instance, E.B. v. France, no. 43546/02, 2008, where the Court held that 'the provisions of Article 8 do not guarantee either the right to found a family or the right to adopt ... The right to respect for "family life" does not safeguard the mere desire to found a family' - para. 41. However, if domestic law creates a right to found a family by, e.g. adopting a child, it must do so without discrimination on, inter alia, the ground of sexual orientation - see also $X$ and Others $v$. Austria (above n. 7).

77 Case C-148/02, Garcia Avello EU:C:2003:539, para. 25; Case C-353/06, Grunkin and Paul EU:C:2008:559, para. 16; Case C-438/14, Bogendorff von Wolffersdorff EU:C:2016:401, para. 32; Coman (above n. 39) para. 38

78 See, among others, Garcia Avello (above n. 77), para. 24; Case C-184/99, Grzelczyk EU:C:2001:458, para. 33; Case C-224/98, D'Hoop EU:C:2002:432, para. 29. For an explanation 
Furthermore, Member States must comply with their obligations regarding the respect of fundamental (human) rights, as these are protected under EU law. The EUCFR provides that Member States are bound by it 'when they are implementing EU law' $^{79}$ the latter having been interpreted, in some cases, broadly, to mean situations that fall within the scope of EU law. ${ }^{80}$ Similarly, fundamental human rights which form part of the general principles of EU law have been held to bind the Member States when they are acting as agents of the $E U,{ }^{81}$ as well as when they derogate from their obligations under EU law, ${ }^{82}$ whilst in some cases the Court went even further, holding that they bind Member States in all situations that fall within the scope of EU law. ${ }^{83}$ Thus, the EUCFR and the general principles of EU law appear to bind the Member States to the same extent, ${ }^{84}$ though, it is not yet entirely clear when national measures can be deemed to fall within the scope of application of EU law for the purposes of EU fundamental rights protection. ${ }^{85}$

Hence, in situations which fall within the scope of EU law by virtue of the fact that a Union citizen has exercised free movement rights, the EU institutions and the Member States must act in a way which is compliant with the free movement provisions and the fundamental human rights that are protected under EU law. ${ }^{86}$ And even if a narrower approach is taken, according to which the above provisions and rights are applicable only in situations where free movement rights are breached (i.e. not merely exercised) and Member States seek to derogate from their obligations under the free movement provisions, situations involving the non-recognition by the host State of rainbow families which have been lawfully established elsewhere are, still, covered since - as will be seen subsequently in this section - in such instances there is always an obstacle to the exercise of free movement rights.

see A. Tryfonidou, The Impact of Union Citizenship on the EU's Market Freedoms (Hart, 2016) 86-88.

Article 51 EUCFR.

See, inter alia, Case C-459/99, MRAX EU:C:2002:461; Case C-390/12, Pfleger EU:C:2014:281.

See, for instance, Case 5/88, Wachauf EU:C:1989:321.

See, for instance, Case C-260/89 ERT EU:C:1991:254.

See, for instance, Case 12/86 Demirel EU:C:1987:400.

C-617/10, Fransson EU:C:2013:105, paras 17-22. M. Dougan, 'Judicial Review of Member State Action under the General Principles and the Charter: Defining the 'Scope of Union Law'" (2015) 52 Common Market Law Review 1201, 1204-1207; P. Craig and G. de Búrca, EU Law: Text, Cases and Material (OUP 2015) 415; R. Schütze, European Union Law (CUP 2018) 480-481. This seems to be, also, supported by the Explanations relating to the Charter of Fundamental Rights [2007] OJ C303/120 (Explanation on Article 51).

P. Craig and G. de Búrca (above n. 84) 415-418; R. Schütze (above n. 84) 478-479.

Writing back in the 1990s, commentators have gone as far as to suggest that as regards obstacles to the free movement of lesbian and gay Member State nationals, ' $\mathrm{t}$ ] here can be little doubt that, as these obstacles hamper the establishment of the internal market (Article 100a and 8a) or the establishment or functioning of the common market (Article 100), the Community has the power and arguably even the duty to propose harmonizing legislation, in accordance with Article 3 (h), aimed at removing these obstacles' - F. Snyder, H. Somsen and H. D. Hoyer, 'Subsidiarity: an Aspect of European Community Law and its Relevance to Lesbians and Gay Men' in K. Waaldijk and A. Clapham (eds), Homosexuality: A European Community Issue (Martinus Nijhoff, 1993) 235. 
Before proceeding to examine whether EU Member States breach their obligations under EU law when they refuse to recognise the familial ties among the members of rainbow families coming from other Member States, it should be underlined that the problem that is examined in this article - i.e. the cross-border legal recognition of the familial ties of rainbow families which have already been lawfully established elsewhere - is different from the situation where a State refuses to allow same-sex couples to become, and be legally recognised as, the joint parents of a child in the first place. In particular, in the former, there is severance of familial ties which have been already validly formed elsewhere, whereas in the latter scenario, what is at issue is the legal choice made by a Member State as to whether it will allow - in the first place - same-sex couples to become the joint parents of a child and to be legally recognised as such. What is more, in the former scenario, the severance of the familial ties is a direct result of the exercise of rights granted by EU law - the exercise of free movement rights - whereas the second scenario involves a purely internal matter which does not have any link with EU law. Since in situations involving the refusal to provide for the cross-border legal recognition of the familial ties in rainbow families that move, the breach of a number of rights emerges as a side-effect of the exercise of $E U$ free movement rights, the EU itself should provide the solution to this problem. ${ }^{87}$ Moreover, the principle of subsidiarity would seem to require this as well, given that Member States acting alone cannot provide a solution, as it is a matter that crosses national boundaries and, thus, requires a certain level of supranational coordination..$^{88}$

\section{V.2 IS THE REFUSAL OF THE HOST STATE TO RECOGNISE THE FAMILIAL TIES AMONG THE MEMBERS OF A RAINBOW FAMILY WHEN THE FAMILY MOVES TO ITS TERRITORY A BREACH OF THE EU FREE MOVEMENT PROVISIONS?}

As noted earlier, the free movement of persons provisions in the FEU Treaty prohibit national measures which impede the free movement of Union citizens between Member States. Union citizens have been given the right to be accompanied or joined by their close family members in the Member State to which they move, exactly because the refusal to allow them to do so would deter them from exercising their free movement rights and would, thus, create an obstacle to free movement. The same rationale lies behind the grant of a number of additional rights to the family of the Union citizen, which have as their aim the smooth integration of the family into the society of the host Member State. As the ECJ has recently emphasised on a number of occasions, the effectiveness of EU free movement rights requires that a Union citizen's family life which has been created or strengthened in one Member State 'may continue when he returns to the Member State of which he is a national' 89

87 For an analysis of this line of reasoning see A. Tryfonidou, Reverse Discrimination in EC Law (Kluwer, 2009) 167-170.

88 H. Stalford (above n. 50) 20.

89 Coman (above n. 39) para. 24; O. and B. (above n. 39) para. 54; Case C-291/05, Eind EU:C:2007:771, para. 36; Case C-40/11, lida (above n. 51), para. 70. 
and, obviously, also, when he settles in a Member State other than that of his nationality.

The same rationale, naturally, applies in the context of rainbow families. To paraphrase the ECJ in its judgment in Carpenter, ${ }^{90}$ the separation of the members of a rainbow family would be detrimental to their family life and, therefore, to the conditions under which the member or members of the family who hold Union citizenship exercise free movement rights. In particular, in situations where a rainbow family moves from a Member State where all its members live together (whether this is because their familial ties are legally recognised in that Member State or not), to one that does not admit one or more of those family members because it does not recognise their familial ties with the Union citizen(s) who exercised free movement rights, there is a clear causal link between the exercise of free movement rights and the loss of the right of the family to live together in the same Member State: it is because a Union citizen moves to a Member State which does not recognise rainbow families that (s)he loses the right to live together with his/her family members.

However, the Court has gone even further and made it clear in Metock, ${ }^{91}$ that even less direct links between a national measure and an obstacle to the exercise of free movement rights suffice for a finding of a breach of EU law: an obstacle to the exercise of the right to move and reside in the territory of another Member State can emerge as a result of a refusal of family reunification rights even in instances where the members of the family had not previously lived together in the territory of another Member State. This is because 'if Union citizens were not allowed to lead a normal family life in the host Member State, the exercise of the freedoms they are guaranteed by the Treaty would be seriously obstructed'. ${ }^{92}$ Hence, it does not matter that the family members have not lived together in the territory of another Member State prior to the exercise of free movement rights: an obstacle to free movement exists as long as there is an exercise of free movement by a Union citizen and a refusal by the host Member State to admit within its territory his/her family members.

It is, thus, clear that in situations where a child is a Union citizen and (s)he is not allowed to be accompanied or joined by both of her parents in the host State because the legal links between the members of the family, as legally established elsewhere, are not recognised in the host State - the child's right to move and reside in the territory of another Member State will be breached. Similarly, in situations where, for the same reason, a Union citizen cannot be accompanied or joined by his/her (same-sex) spouse/partner and/or the children of the couple, (s)he will be deterred from exercising free movement rights. ${ }^{93}$ Accordingly, and since Directive $2004 / 38$ - a piece of secondary legislation - needs to be read in a way which complies with primary EU law provisions, and, in particular, with the free movement provisions

\footnotetext{
90 Case C-60/00, Carpenter EU:C:2002:434.

91 Case C-127/09, Metock and Others EU:C:2008:449, paras 58-70. For an explanation of this aspect of the judgment see C. Berneri (above n. 36) 58-61.

$92 \quad$ Metock (above n. 91) para. 62.

93 For a similar argument in the US context see A. Koppelman (above n. 30) 74-76.
} 
and the prohibition of discrimination on, inter alia, the ground of sexual orientation as laid down in Article 21 EUCFR, ${ }^{94}$ the terms 'descendants' and 'relatives in the ascending line' must be read in a way which includes children and parents which constitute a rainbow family. ${ }^{95}$ The same approach should, obviously, be followed when interpreting the judge-made term 'primary carer', for the purposes of Articles 20 and 21 TFEU.

In addition - and to take the argument even further - it would seem that the mere negative climate towards rainbow families in a certain Member State may be capable of impeding the free movement of such families to that Member State and may, thus, constitute an obstacle to free movement. Whether this would amount to a potential obstacle - and would, thus, be caught by EU free movement law - or, simply, a hypothetical obstacle - which would, as such, escape the ambit of the free movement provisions, is not entirely clear, as the distinction between the two is rather nebulous. ${ }^{96}$ Situations which involve action that creates a negative climate against a specific minority have been held to be contrary to EU anti-discrimination law and, in particular, Directive 2000/78, ${ }^{97}$ even if there is no identifiable 'victim'. In Asociația

Moreover, Recital 31 of Directive 2004/38 provides that the Directive 'respects the fundamental rights and freedoms and observes the principles recognised in particular by the Charter of Fundamental Rights of the European Union. In accordance with the prohibition of discrimination contained in the Charter, Member States should implement this Directive without discrimination between the beneficiaries of this Directive on grounds such as [...] sexual orientation'.

Whether a uniform, autonomous, EU interpretation of these terms which does not make reference to national legislation (whether of the home State or the host State) or whether the home State or host State principle should be adopted for this purpose, will need to be clarified by the ECJ, once and if it is given the opportunity. If the former option is chosen (i.e. autonomous, EU, definition) and the definition provided considers the children of same-sex parents as the children of both of their parents for the purposes of EU free movement law, this will mean that in situations where rainbow families move between Member States, they will be able to rely on Directive 2004/38 to require the host Member State to admit the whole family within its territory, recognising - for that purpose - the familial links between the children of the family and both of their parents. Of course, in order for the familial ties among the members of a rainbow family to be legally recognised in the host State, they must have been legally established somewhere, though it is not necessary that these are established and/or recognised in the Member State from which the family moves. If the home State principle is chosen, on the other hand, some - albeit more limited - protection will be afforded, as this will require that rainbow families that are recognised as families in their home Member State will be able to carry their status and the legal recognition of their familial links with them to the host State, when claiming family reunification rights. Conversely, if the host State principle is chosen, this will mean that the host State will be allowed to refuse to recognise the links between the children of rainbow families and both of their parents, and, thus, refuse them family reunification rights, irrespective of whether those links are legally recognised in the Member State from which the family comes.

See A. Tryfonidou, '(Further) Signs of a Turn of the Tide in the CJEU's Citizenship Jurisprudence: Case C-40/11, lida, Judgment of 8 November 2012', (2013) 20 Maastricht Journal of European and Comparative Law 302, 307-313.

Directive 2000/78 establishing a general framework for equal treatment in employment and occupation [2000] OJ L 180/22. 
Accept, ${ }^{98}$ the ECJ found that the prohibition of discrimination on the ground of sexual orientation under the 2000 Directive could be breached simply as a result of a homophobic statement made by a person associated with a football team with regards to the appointment of gay football players in general (i.e. without there being an identifiable, openly gay or bisexual, player who had been refused employment or dismissed by the said football team). This demonstrates that the prohibition laid down in the above instrument aims not merely to eradicate specific instances of discrimination on the prohibited grounds but, also, more broadly, a negative climate against members of specific minorities. ${ }^{99}$ Whether the free movement provisions can be breached by national laws which lead to such a negative climate remains to be seen, nonetheless.

Now, assuming that a rainbow family is actually admitted to the host Member State, this is not the end of the story. If the host Member State does not legally recognise the family ties between the members of the family for other legal purposes (e.g. tax law, property law, inheritance law, nationality law, pensions, and so on) this will cause great inconvenience to the members of the family which, in its turn, will impede the exercise of their free movement rights. In Garcia Avello and Grunkin Paul, ${ }^{100}$ the ECJ noted that the denial of the host State to recognise the surnames of Union citizens registered in another Member State and the resultant discrepancy in surnames in different Member States, led to serious inconvenience for the persons concerned which, in its turn, was likely to deter them from exercising their free movement rights. If we transpose this reasoning to the context of rainbow families, it is clear that the denial of the host State to legally recognise the familial ties between the members of the family - as these are legally recognised in one of the EU Member States - once the family is within its territory, and the resultant discrepancy in the legal ties among the members of the family in different EU Member States, can constitute an obstacle to free movement. ${ }^{101}$ Again, the causal link between the contested refusal to recognise the familial links among the family members and the obstacle to free movement is obvious: it is because a Union citizen wishes to move to a Member State that does not recognise rainbow families that his/her familial links will not be legally recognised and, as a result of that, (s)he and his/her family will suffer serious inconvenience due to the discrepancy in the legal ties recognised in different Member States. ${ }^{102}$

Case C-81/12, Asociaţia Accept EU:C:2013:275. For excellent commentary on the case see U. Belavusau, 'A Penalty Card for Homophobia from EU Non-Discrimination Law: Comment on Asociaţia Accept (C-81/12)' (2015) 21 Columbia Journal of European Law 329.

A. Tryfonidou, 'Discrimination on the Grounds of Sexual Orientation and Gender Identity' in S. Vogenauer and S. Weatherill (eds), General Principles of Law: European and Comparative

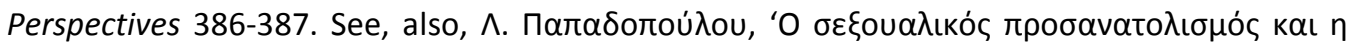

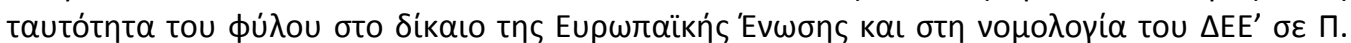

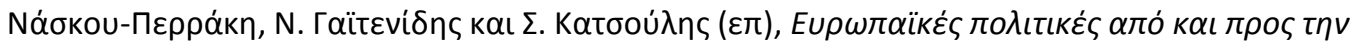

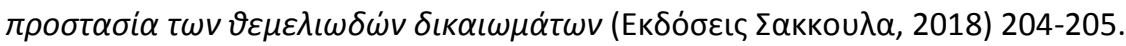

For a similar argument see H. Toner, 'Migration Rights and Same-Sex Couples in EU Law: A Case Study' in K. Boele-Woelki and A. Fuchs (eds), Legal Recognition of Same-Sex Relationships in Europe: National, Cross-Border and European Perspectives (Intersentia, 2012) 304-305. 
As is well-known, a finding that a measure can impede the exercise of free movement does not, automatically, mean that there is a breach of EU law. Obstacles to free movement can be justified on a number of (non-economic) grounds, which are either explicitly noted in the Treaty (the Treaty derogations) or which have been established in the Court's case-law (the objective justifications). In cases involving rainbow families and their refusal to recognise them, Member States would probably try to rely on the ground of public policy - which is one of the Treaty derogations - and their interest in preserving their national identity, ${ }^{103}$ as was done in the recent case of Coman, where Romania refused to recognise a same-sex marriage lawfully concluded in another Member State for the purpose of granting family reunification rights. However, and agreeing with the ECJ in Coman, an obligation to (simply) recognise the status attached to a same-sex relationship in another EU Member State and - I would add - to recognise the parental linkage (as established elsewhere) between one or both of the parents in a same-sex relationship and their child, 'does not undermine the national identity or pose a threat to the public policy of the Member State concerned' ${ }^{104}$ Such an obligation in no way requires a Member State to introduce, within its territory, legislation that enables same-sex couples to create a family and to be legally established as the joint parents of a child, but it merely requires a Member State to refrain from severing the legal links between a child and his/her parent(s) as these have already been established elsewhere, as otherwise there would be an obstacle to free movement. ${ }^{105}$

movement can only arise if the familial ties are legally recognised in a Member State (usually this being the home Member State) and, thus, there will be a discrepancy in the recognition of the legal ties among the members of the family in different EU Member States.

Article 4(2) TEU.

Coman (above n. 39) para. 46.

The Court in Coman (above n. 39) used the requirement of 'genuine residence' (introduced in a previous case which did not involve same-sex couples (O. and $B$ (above n. 39), para. 51-54) in order to ensure that same-sex couples cannot evade the laws of their Member State of nationality and residence by trying to introduce same-sex marriage through the backdoor. In particular, in Coman it was made clear that same-sex spouses can claim family reunification rights on their return to their Member State of nationality only if they have taken-up genuine residence (i.e. residence for over three months) in the territory of another Member State and during that period of genuine residence they have established and strengthened family life in the territory of that State. This means that an LGB Union citizen cannot simply visit another Member State for a few days simply in order to get married to his/her same-sex partner, and then return to his/her Member State of nationality where, relying on EU law, (s)he will require that State to recognise his/her spouse as a spouse for the purpose of family reunification. This, also, means that it is likely that in case it is made clear that EU law requires the Member State to which a rainbow family moves/returns to legally recognise the familial links among the members of the family, this will be the case only if the family has taken-up 'genuine residence' in the territory of another Member State during which it established and strengthened family life. Hence, for instance, French women who cross the border to Belgium for a few days to undergo artificial insemination (in this way evading the French prohibition on artificial insemination by lesbian couples), will not be able on their return to France to rely on EU free movement law to require that Member State to recognise the familial links among the members of their family, as the requirement of 'genuine residence' in the territory of another Member State will not have been satisfied - for a study into the experiences of French lesbian women who go to Belgium to undergo assisted reproduction therapy see W. Van Hoof, G. Pennings, P. De Sutter, 'Cross-border reproductive care for law evasion: A qualitative study into the 
In any event, even if it is accepted that the contested refusal of recognition can, in principle, be justified on the above grounds, the offending Member States will still face a number of other hurdles when seeking to derogate from their obligations under the free movement provisions.

As laid down in Article 27(2) of Directive 2004/38, measures taken by the host Member State relying on the public policy ground 'shall be based exclusively on the personal conduct of the individual concerned'. This will, clearly, not be satisfied where Member States engage in a blanket refusal to legally recognise the exact family ties of the members of all rainbow families, as in this way they impede the free movement rights of a whole category of persons (LGB individuals who are in a same-sex relationship and their children), and, hence, the exclusion of those persons from free movement is not based on their personal conduct.

Furthermore, as is well-established, a national measure that is liable to obstruct the exercise of freedom of movement for persons may be justified only where such a measure is consistent with the fundamental (human) rights which are guaranteed under EU law. ${ }^{106}$ As will be seen in the next sub-section, the refusal to legally recognise the familial links between a child and his/her parent(s) in a rainbow family, as these have been established elsewhere, is capable of breaching a number of fundamental human rights that the child derives from the EUCFR and which are, also, protected as general principles of EU law. Hence, and also for this reason, the obstacle to free movement that emerges as a result of the refusal of the host State to recognise the familial links among the members of a rainbow family, cannot be justified.

Accordingly, the refusal of the host Member State to legally recognise the familial ties among the members of a rainbow family, as these have been legally established elsewhere, amounts to a breach of the EU free movement provisions. This is so, in particular, when it leads to a) the denial of family reunification rights, and/or b) the denial of rights to which the family would have been entitled to after gaining access to the territory of the host State if it was legally recognised as a 'family', such as social assistance benefits, pension entitlements, and tax advantages which are reserved for legally recognised 'families'.

\section{V.3 IS THE REFUSAL OF THE HOST STATE TO RECOGNISE A RAINBOW FAMILY AS A 'FAMILY' A BREACH OF FUNDAMENTAL HUMAN RIGHTS PROTECTED UNDER EU LAW?}

Under EU law, fundamental human rights have been protected as part of the general principles of EU law since the late 1960s. ${ }^{107}$ With the coming into force of the Treaty

experiences and moral perspectives of French women who go to Belgium for treatment with donor sperm' (2015) 124 Social Science \& Medicine 391. 
of Lisbon in 2009, the Treaty on European Union (TEU) has been amended, and, as a result of that, its Article 6 provides that the EUCFR has the same legal value as the Treaties and, thus, produces legally binding effects. ${ }^{108}$ Hence, in the EU, there are currently two parallel sources of fundamental human rights protection, which, to a great extent, overlap: the EUCFR and the general principles of EU law. For our purposes, the Treaty of Lisbon changes are, also, important in that they added 'protection of the rights of the child' to the list of general objectives of the EU, 109 which, essentially, means that the interpretation of the provisions of the constituent EU Treaties (the TEU and TFEU), as well as all EU actions, must be informed by, inter alia, this objective. As noted by the Commission in its EU Agenda for the Rights of the Child '[t]he action of the EU should be exemplary in ensuring the respect of the provisions of the Treaties, the Charter of Fundamental Rights of the European Union and of the UNCRC with regard to the rights of children' ${ }^{110}$

Although the ECHR is not an EU instrument, it has, nonetheless, always had a significant impact on the development of EU fundamental human rights protection, being recognised as a source of 'guidelines' for the ECJ when determining which fundamental human rights form part of the general principles of EU law and how these must be interpreted. ${ }^{111}$ In addition, it plays a crucial role in the interpretation of the EUCFR, as Article 52(3) of the latter provides that 'In so far as this Charter contains rights which correspond to rights guaranteed by the Convention for the Protection of Human Rights and Fundamental Freedoms, the meaning and scope of those rights shall be the same as those laid down by the said Convention. This provision shall not prevent Union law providing more extensive protection'. The latter proviso demonstrates that although the approach adopted in the jurisprudence of the European Court of Human Rights (ECtHR) can inform the ECJ's rulings on the protection of fundamental rights which are protected under EU law, there is nothing to stop the Luxembourg Court from providing more extensive protection than its Strasbourg counterpart.

Given that there have been no $E C J$ rulings which can contribute to the development of an argument in cases involving rainbow families, the analysis that will follow will consist of an examination of the jurisprudence of the ECtHR on the parent-child relationship, as this can, clearly, inform the argument that EU law requires the crossborder legal recognition of rainbow families. However, it is important to remember that, as noted in the previous paragraph, the protection afforded by EU law can be more extensive than that provided under the ECHR, especially in view of the fact that the Preamble to the Charter states that it aims to 'strengthen the protection of fundamental rights' in the light of 'changes in society' and 'social progress'. Hence, the ECtHR jurisprudence that will be analysed merely provides a floor which the EU can

T. Hickman, 'Beano No more: The EU Charter of Rights After Lisbon' (2011) 16 Judicial Review 113.

Article 3(3) TEU.

110 Communication from the Commission to the European Parliament, the Council, the European Economic and Social Committee, and the Committee of the Regions: An EU Agenda for the Rights of the Child $\operatorname{COM}(2011) 60$ final, p. 14. 
use as a basis for developing more extensive rights in situations involving rainbow families that move between EU Member States. ${ }^{112}$

As will be seen, the ECtHR interpretation of a number of ECHR rights can, clearly, assist rainbow families. Accordingly - and given that all EU Member States are signatories to the ECHR - rainbow families may be able to have recourse to the ECHR in order to obtain redress when the EU Member State to which they move refuses to recognise the legal ties among their members, as these are legally recognised in other countries. However what this article will aim to show is that if rainbow families wish to have recourse to EU law in order to require the host Member State to recognise the familial ties among their members, they can clearly do so, not merely by relying on the EU free movement provisions (as seen in the previous sub-section) but, also, by relying on the fundamental human rights protection offered by EU law. ${ }^{113}$

One point that should be underlined is that, so far, all cases of the ECtHR involving rainbow families have been approached from the point of view of the parents - in other words, the question has been whether the rights enjoyed by the parents have been breached as a result of the contested national measure. ${ }^{114}$ In this article, however, a different perspective will be taken (that of the child) and, thus, the question will be whether the contested severance - in law - of the familial ties in rainbow families in cases where the family moves between EU Member States, can breach the fundamental human rights of the children of rainbow families. In addition, many of the issues raised in situations involving the children of rainbow families have been raised in different contexts - e.g. in situations involving single-parent families or where an opposite-sex couple had recourse to a surrogacy arrangement. For the purposes of this article - and where appropriate ${ }^{115}$ - the principles established in those cases will be transposed to the context of rainbow families and, in particular, when such families move between EU Member States.

112 J. Rijpma and N. Koffeman (above n. 6) 465.

113 For a comparison between the ECJ and ECtHR approaches to sexual orientation and gender identity discrimination see R. Wintemute, 'In Extending Human Rights, which European Court is Substantively "Braver" and Procedurally "Fitter"?' in S. Morano-Foadi and L. Vickers (eds), Fundamental Rights in the EU (Hart, 2015).

114 For a criticism of this approach which seems to be leaving the question of the child's best interests outside the equation see the dissenting opinion of Judge Villiger in Gas and Dubois (above n. 7).

115 It should be kept in mind that for some legal purposes, the situation of a rainbow family is not similar to that of a family comprised of an opposite-sex couple and their children; in particular, the classic distinction between married and unmarried couples - endorsed by the ECtHR - is maintained in this context as well: accordingly, an unmarried (same-sex) couple is considered not to be similarly situated with a married (opposite-sex) couple, for most legal purposes - see, for instance, Boeckel and Gessner-Boeckel v. Germany, no. 8017/11 (case declared inadmissible). 


\section{V.3.1. Breach of the Right to Private and Family Life}

The right to private and family life is protected as a general principle of EU law, ${ }^{116}$ as well as under Article 7 EUCFR. ${ }^{117}$ In fact, the right consists of four separate (sub-)rights: the right to private life, the right to family life, the right to a home, and the right to communications. In this part of the article, it will be argued that in situations where the host Member State refuses to legally recognise the child-parent relationship, as this has been lawfully established in another country, the child of a rainbow family can rely on the private and family life aspects of Article 7 EUCFR and the general principles of EU law, to claim that there is a breach of EU law.

The ECtHR held in Gas and Dubois v. France that a same-sex couple and their child(ren) can together enjoy 'family life', within the meaning of Article 8 ECHR. ${ }^{118}$ This follows the general approach of the ECtHR, according to which biological ties are not an overriding factor in establishing family life and some evidence of real and constant relationship is normally required before such relationships are afforded the protection of Article 8 ECHR. ${ }^{119}$ Accordingly, the ECtHR has made it clear that the non-biological parent of a child in a rainbow family can be considered a 'parent' for the purposes of Article $8 \mathrm{ECHR}$, provided that the relationship between the two resembles what is perceived to be 'the norm' of the nuclear family. ${ }^{120}$ Obviously, the same interpretation must be followed for the purposes of Article 7 EUCFR. Hence, in situations where the child in a rainbow family has established de facto 'family ties' with both of his/her parents, it is undisputed that family life exists between the members of the family; and, a fortiori, this is the case when those family ties have, already, been legally recognised somewhere.

Yet, the ECtHR is still of the view that it is up to the signatory states to determine whether they will afford the right to same-sex couples to become parents jointly and, if yes, whether they will afford any legal recognition to the de facto familial ties among the members of a rainbow family. ${ }^{121}$ Accordingly, even though the members of a rainbow family can enjoy 'family life' within the meaning of Article $8 \mathrm{ECHR}$, it is not a breach of that provision if the State where the family lives does not legally recognise

116 See, e.g. Carpenter (above n. 90), para. 41.

117 Article 7 EUCFR provides: 'Everyone has the right to respect for his or her private and family life, home and communications'. For an analysis of the ECJ's approach towards the right to family life under EU law see S. Iglesias Sánchez and K. Carr, 'The right to family life in the EU Charter of Fundamental Rights' in M. González Pascual and A. Torres Pérez (eds), The Right to Family Life in the European Union (Routledge, 2017).

118 Gas and Dubois v. France (above n. 7), para. 37. See, also, $X$ and Others v. Austria (above n. 7) paras 95-96; Boeckel and Gessner-Boeckel v. Germany (above n. 115) para. 27. The Court, also, held that a trans man, his female partner, and their child which was biologically related only to the female partner can enjoy 'family life' within the meaning of Article $8 \mathrm{ECHR}-$ see $X, Y$ and $Z$ v. UK, App. No. 21830/93, 1997, para. 37.

J.R.M. v. the Netherlands, no. 16944/90, 1993; Nylund v. Finland, no. 27110/95, 1999; K. and T. v. Finland, no. 25702/94, 2001. See L. Hodson (above n. 7) 507-509; G. Van Bueren, Child rights in Europe (Council of Europe Publishing, 2007) 119.

C. McGlynn (above n. 10) 15.

121 See footnote 76 above. 
the familial ties among (some of) the members of the family and, in particular, between a child and his/her non-biological parent. This seems to be in line with the ECtHR's ruling in Marckx v. Belgium, ${ }^{122}$ where it was held that Article 8 'implies the existence in domestic law of legal safeguards that render possible as from the moment of birth the child's integration in his [biological] family'. ${ }^{123}$ The same approach was subsequently taken in Johnston $v$. Ireland, ${ }^{124}$ where the ECtHR found Ireland to be in breach of the right to family life of a child and her (biological) parents, as a result of the fact that the child's natural family ties to her (biological) father could not be legally recognised because her parents could not marry on account of the indissolubility due to the Irish constitutional prohibition on divorce at the time - of the father's marriage to another woman with whom he had separated. In both of these cases the ECtHR seems to have emphasised the biological connection between the child and his/her parent and, thus, the obligation imposed on States to provide legal recognition to the parent-child relationship by making provision in their laws for that relationship to be established in law, seems to be confined to situations where the parent and the child are biologically related. ${ }^{125}$ Hence, when it comes to rainbow families, the above rulings can only help children whose familial ties with their biological parent are not legally established, but they come empty-handed for children who wish to have their familial ties with their non-biological parent established $a b$ initio. ${ }^{126}$

However, the facts of the above cases were confined within one and the same State and did not touch on the issue of the cross-border legal recognition of the parent-child relationship. Moreover, as we saw, they did not concern the relationship between a child and his/her non-biological parent.

The ECtHR was confronted with both of the above issues in Wagner v. Luxembourg, ${ }^{127}$ albeit not in a context involving a rainbow family. At issue in the case was the refusal of the Luxembourg authorities to recognise the Peruvian court decision pronouncing the full adoption by Ms Wagner - a Luxembourg national - of her child, JMWL, of Peruvian nationality. The refusal was the result of the absence in the Luxembourg legislation of provisions allowing an unmarried person to obtain full adoption of a child. The Court held that this refusal amounted to an unjustified interference with the right to respect for Ms Wagner's and her child's family life and, thus, amounted to an infringement of Article 8 ECHR. The Court, in particular, noted that '[b]earing in

122 Marckx v. Belgium (above n. 31).

123 ibid., para. 31.

124 Johnston v. Ireland, no 9697/82, 1986.

125 This was expressly noted by the court in $X, Y$ and $Z v$. UK (above n. 118) para. 43. This is also obvious from a number of subsequent cases where the same reasoning was followed. See, for instance, Kroon v. The Netherlands, App. No. 18535/91, 1994. For an analysis of the principles established in ECtHR case-law relating to the de facto family see C. O'Mahony, 'Irreconcilable Differences? Article 8 ECHR and Irish Law on Non-Traditional Families' (2012) 26 International Journal of Law, Policy and the Family 31, 34-37.

126 See the ECtHR's more restrictive approach in a case which did not involve a 'traditional' (heterosexual) family but a family where the link that was sought to be established was between a trans (non-biological) parent and his child - see $X, Y$ and $Z v$. UK (above n. 118). 
mind that the best interests of the child are paramount in such a case ... the Court considers that the Luxembourg courts could not reasonably disregard the legal status validly created abroad and corresponding to a family life within the meaning of Article 8 of the Convention.' ${ }^{128}$

The case, therefore, demonstrates that Article $8 \mathrm{ECHR}$ requires the contracting States to pursue the cross-border continuity of family ties. In other words, the ECHR signatory States are required by this provision to legally recognise family ties which have been lawfully established in another country. As noted by another commentator, the right to respect for private and family life, therefore, requires that "limping" situations - i.e. situations where a personal status is recognized under the law of State $X$ but not under the law of State $Y$ - should be avoided to the largest possible extent'. ${ }^{129}$

This principle can, clearly, prove very helpful for rainbow families who move between EU Member States in exercise of their EU free movement rights: the children of such families can rely on the Wagner ruling in order to claim that the host Member State is in breach of their right to family life (as is protected under Article 7 EUCFR and as a general principle of EU law) as a result of refusing to pursue the cross-border continuity of their family ties. What is more, such a reading of the right to family life seems to be in line with ECJ pronouncements where the Court emphasised the importance of ensuring that Union citizens who move can continue to lead a normal family life in the host Member State. ${ }^{130}$

More recently, the ECtHR was called to rule in a case which involved the cross-border recognition of a parent-child relationship lawfully established abroad, albeit in the more controversial context of a surrogacy arrangement (Mennesson $v$. France). ${ }^{131}$ The ECtHR, following the principles established in Wagner v. Luxembourg, found that the contested refusal of France to recognise a surrogacy agreement entered into abroad, and the resultant refusal to legally recognise the parent-child relationship as established by this agreement, amounted to a breach of Article 8 ECHR. However, unlike in Wagner, in this case, the ECtHR found that there was a breach of Article 8 ECHR as regards the children's right to private life only. In particular, the Court found that, on the facts of the case, the lack of recognition of the parent-child relationship did not disproportionally affect the applicants' ability to enjoy their family life in a

128 Ibid., para. 133. See, also, Negrepontis-Giannisis v. Greece, no. 56759/09, 2011, which involved the cross-border legal recognition of an adoption lawfully concluded in another country (the US), albeit of an adult.

129

P. Franzina, 'Some remarks on the relevance of Article 8 of the ECHR to the recognition of family status judicially created abroad' (2011) 3 Diritti umani e diritto internazionale 609, 611.

See, inter alia, Metock (above n. 91) para. 62. In two more recent cases the Court, in particular, noted that '[t]he rights which nationals of Member States enjoy' under Article 21(1) TFEU 'include the right to lead a normal family life, together with their family members, both in the host Member State and in the Member State of which they are nationals when they return to that Member State.' - Coman (above n. 39) para. 32 and Case C-165/16 Lounes EU:C:2017:862, para. 52. For a similar argument see H. Toner (above n. 101) 307-308.

Mennesson v. France, no. 65192/11, 2014. See, also, Labassee v. France, no. 65941/11, 2014 and Laborie v. France, no. 44024/13, 2017. 
practical sense, and, thus, did not amount to a breach of their right to family life. There was, nonetheless, a breach of the right to private life of the children, since 'respect for private life requires that everyone should be able to establish details of their identity as individual human beings, which includes the legal parent-child relationship'; ${ }^{132}$ the 'legal uncertainty' caused as a result of the non-recognition in the host State is liable to have negative repercussions on the children's definition of their personal identity.

The case involved surrogacy which, as noted earlier in this article, is still largely prohibited within Europe, and this is so both for same-sex and opposite-sex couples. This may, in fact, be the reason behind the possible limitation of the effect of the ruling to situations involving the relationship between the children which have been born as a result of a surrogacy arrangement, on the one hand, and their intended biological parent, on the other. In particular, in the Mennesson case, one of the intended parents of the children (the father) was, also, their biological parent and the ECtHR in its ruling noted this 'special dimension' of the case and that 'it cannot be said to be in the interests of the child to deprive him or her of a legal relationship of this nature where the biological reality of that relationship has been established and the child and parent concerned demand(ed) full recognition thereof ... by thus preventing both the recognition and establishment under domestic law of their legal relationship with their biological father, the respondent State overstepped the permissible limits of its margin of appreciation'. ${ }^{133}$ This has caused one commentator to wonder whether the result in Mennesson would 'have been the same in a case where none of the intended parents was the biological parent' and whether 'the obligation of recognition exist[s] regarding the biological father only or also the intended mother'. ${ }^{134}$ If this is, indeed, the case, it would mean that, when it comes to parent-child relationships established through surrogacy agreements, Article 8 ECHR merely requires signatory States to legally recognise the relationship between a child born through such an arrangement and his/her biological parent. This is, nonetheless, a point which awaits further clarification from the ECtHR. ${ }^{135}$

132 Mennesson v. France (above n. 131), para. 96.

133 Emphasis added.

134 I. Rein-Lescastereyres (above n. 21) 128. In the subsequent case of Foulon and Bouvet v. France, no. 9063/14 and 10410/14, 2016 the Court followed the same approach in a case which involved an application for the cross-border legal recognition of the parent-child relationship between the biological father and a child that was born as a result of a surrogacy arrangement. In this case, the father was in a same-sex relationship but there was no request for the recognition of the parent-child relationship between the child and the father's partner, who was not biologically related to the child. In Paradiso and Campanelli v. Italy, no. 25358/12, 2017, where the intended parents of a child born in Russia as a result of a surrogacy arrangement were not biologically connected to the child, the ECtHR found that the intended parents and the child did not enjoy 'family life' within the meaning of Article $8 \mathrm{ECHR}$ - this, however, was not merely based on the absence of a biological connection between the child and the intended parents but also on other factors, namely, the short duration of the relationship between the child and the intended parents and the uncertainty of the ties from a legal perspective (given that the parents had acted illegally).

135 G. Cano Palomares, 'Right to family life and access to medically assisted procreation in the case law of the European Court of Human Rights' in M. González Pascual and A. Torres Pérez (eds), The Right to Family Life in the European Union (Routledge, 2017) 108. 
Hence, the ECtHR has made it clear in a number of judgments that Article 8 ECHR is breached where there is de facto family life, and familial ties which have been legally established in another State are severed in the country of residence of the family. In particular, Article 8 ECHR requires signatory States to provide a legal framework for enabling the biological parent of a child to be recognised as the legal parent of the child and for the child to be integrated into that person's family of origin (Marckx). In addition, the same provision requires signatory States to recognise the parent-child relationship - as this has been legally established in another country - between a child and his adoptive parent(s) (Wagner). The waters are somewhat muddier, nonetheless, when it comes to the cross-border legal recognition of a parent-child relationship established through a surrogacy agreement, as there are indications in the case-law that there is an obligation to recognise a parent-child relationship in such a context merely between a child and his/her (intended) biological parent (Mennesson).

Although the relevant cases did not involve rainbow families, nor did they involve movement between EU Member States, similar legal argumentation can be pursued in situations involving the cross-border legal recognition of the legal status attached to the members of a rainbow family which moves between EU Member States. ${ }^{136}$

Therefore, and transposing this interpretation of Article 8 ECHR into the EU context, the failure of the host Member State to legally recognise the familial ties between a child of a rainbow family and one or both of his/her parents, as these have been legally established elsewhere, can amount to an interference with the child's rights to private and family life, protected as a general principle of EU law and under Article 7 EUCFR. This is, clearly, the case in all instances where the host Member State refuses to recognise the relationship between the child and his/her biological parent. As regards the non-biological parent, an interference with the rights to private and family life will emerge in situations where the child has been adopted, but it is unclear whether this is the case where the rainbow family has resorted to assisted procreation techniques or surrogacy. In any event, even if the ECtHR deems it necessary to limit its rulings in the above way, the EU institutions (including the ECJ, if the case which involves the issue is referred to it) may decide to grant more extensive protection. This is the case especially if the right to private and family life is read in the light of Article 33 EUCFR,

136 Nonetheless, it should be noted that that ECtHR may in fact adopt a different approach to the interpretation of the above provisions and, in particular, when examining whether a measure is justified, in situations where rainbow families are involved. As noted by another commentator, 'the child's welfare, in cases of adoption by gay or lesbians, is barely considered. Instead of the best interests of the child, the Court focuses on the applicants' sexual orientation and the recognition of sexual minorities' rights in Europe. The Court relies on the existence of a European consensus to avoid deciding on specific issues that are of controversial understanding among the European countries.' - G. Alves de Faria, 'Sexual Orientation and the ECtHR: what relevance is given to the best interests of the child? An analysis of the European Court of Human Rights' approach to the best interests of the child in LGBT parenting cases', (2015) Family and Law available at <http://www.familyandlaw.eu/tijdschrift/fenr/2015/04/FENR-D-15-00002> (accessed on 18.12.2018). Yet, the word 'may' above is in italics, as the ECtHR's approach towards the issue of 'European consensus' appears to differ from case to case, and this is so also in cases where the facts involve the parenting rights of single LGB persons or same-sex couples. For a criticism of the (inconsistent) use of the notion of 'European consensus' by the ECtHR see P. Johnson, Homosexuality and the European Court of Human Rights (Palgrave, 2014) 77-83. 
which provides that ' $t$ the family shall enjoy legal, economic and social protection'. From the moment that a rainbow family is recognised as enjoying 'family life' and is, thus, 'a family', then it attracts, also, 'legal protection' under EU law; this can clearly be translated into an obligation imposed by EU law on Member States to ensure the cross-border continuity of the legal ties among the members of the family, wherever they move within the EU, without imposing any biological limitations.

Nonetheless, the right to private and family life is not an absolute right and States are allowed to justify their measures which interfere with its exercise. And - as clarified by the Explanations attached to the Charter which were given interpretative effect by Article 6(1) TEU and Article 52(7) EUCFR ${ }^{137}$ - the limitations that can legitimately be imposed on this right by Article 7 EUCFR are the same as those allowed under Article $8 \mathrm{ECHR}$. This means that the interference must have been conducted 'in accordance with the law', must further a legitimate aim of those mentioned in Article 8(2) ECHR, and must be necessary in a democratic society. Of course, in line with Article 52(3) EUCFR, the interpretation of these limitations can be narrower - and, thus, afford more extensive protection to the right itself - when applied for the purposes of Article 7 EUCFR.

Given that it is fairly clear and foreseeable that Member States who do not recognise rainbow families, will do so also in situations which involve rainbow families that come from other Member States, the interference can be considered to be in accordance with the law.

However, can the contested refusal be justified by the 'legitimate aims' laid down in Article 8 ECHR? Member States would most likely argue that their refusal to legally recognise the family ties among the members of rainbow families coming from other Member States has two aims, i.e. the 'protection of morals' - with the specific aim of supporting and encouraging the family in the traditional sense which 'is, in principle, a weighty and legitimate reason'138 - as well as 'the protection of the rights of others' (in this case, 'others' being read as referring to 'children').

The aim of supporting and encouraging the traditional family has been recognised as a valid objective by the ECtHR, ${ }^{139}$ and, thus, can, also, form a possible justification, when examining the issue from the point of view of EU law. However, such a justification would most likely fail, because - to use the reasoning employed in Marckx v. Belgium - 'in the achievement of this end recourse must not be had to measures whose object or result is ... to prejudice the' rainbow family, given that the members of the rainbow family can - as established in Gas and Dubois v. France - enjoy family life. Accordingly, the members of rainbow families who enjoy family life must 'enjoy the guarantees of Article 8 on an equal footing with the members of the traditional Explanations relating to the Charter of Fundamental Rights (above n. 84), Explanation on Article 52.

138 Karner, no. 40016/98, 2003, para. 40.

139 See for instance Ibid and Vallianatos (above n. 75) para. 83. 
family'. ${ }^{140}$ Moreover, as another commentator has rightly argued, 'The standard "traditional family" defence would suggest that, by reducing non-heterosexual family rights to the greatest extent possible, national laws disincentivize non-traditional family structures, prioritize heterosexual marriage relationships, and encourage individuals into a socially optimal family model. However ... such an argument would be intellectually weak (not to mention wholly removed from social reality). Severing the legal connection between gay, lesbian, and bisexual parents and their nonbiological children does not persuade such individuals to enter an opposite-gender heterosexual marriage ... instead of reinforcing the de facto social superiority of traditional families, the absence of LGB family rights has no appreciable impact on heterosexual marriage, but significantly impedes lesbian, gay, and bisexual family life'. ${ }^{141}$

In any event, even if the above aim could, prima facie, justify the interference with the rights to private and family life in this context, it is unlikely to be found proportionate. The ECtHR has noted that the fact that an essential aspect of the identity of individuals is at stake where the legal parent-child relationship is concerned' means that the margin of appreciation afforded to States needs to be reduced. ${ }^{142}$ And, as the same court has noted, ${ }^{143}$ in cases where the margin of appreciation afforded to States is narrow the principle of proportionality does not merely require that the measure chosen is in principle suited for realising the aim sought. It must also be shown that it was necessary in order to achieve that aim to exclude certain categories of people' from a certain entitlement. For the reasons explained above, it cannot be shown that it is necessary, in order to protect the family in the traditional sense, to deprive the children of rainbow families of the entitlement to have their relationship with both parents - as established elsewhere - legally recognised in the Member State to which they move.

140 Marckx v. Belgium (above n. 31) para. 40.

141 P. Dunne (above n. 27) 48-49. See, also, J. M. Scherpe, 'The Legal Recognition of Same-Sex Couples in Europe and the Role of the European Court of Human Rights' (2013) 10 The Equal Rights Review 83, 92; and N. D. Polikoff, 'This Child does have two mothers: Redefining parenthood to meet the needs of children in lesbian-mother and other non-traditional families' (1990) 78 Georgetown Law Journal 459, 486

See, for instance, Mennesson v. France (above n. 131) paras 77 and 80; Oliari v. Italy (above n. 75) paras 162-177; Orlandi, no. 26431/12, 26742/12, 44057/12, 60088/12, 2017, para. 203. In all these cases, the ECtHR noted that when there is 'no consensus within the Member States of the Council of Europe, either as to the relative importance of the interest at stake or as to the best means of protecting it, particularly where the case raises sensitive moral or ethical issues, the margin will be wider', however, it also went on to point out that 'where a particularly important facet of an individual's existence or identity is at stake the margin allowed to the State will be restricted'. As noted by Johnson (above n. 135) the notions of the margin of appreciation and the European consensus are used inconsistently by the ECtHR and, thus, it is difficult to predict how the analysis will be conducted on the facts of a particular case. In all the above cases, nonetheless, the ECtHR appeared to leave a narrow margin of appreciation to the signatory states even though there was not a clear European consensus with regards to the relevant matters. 
For similar reasons, a justification based on the need to protect the rights of others, namely the rights of the children of rainbow families, would also be bound to fail. It is well-known that the main argument of opponents of the legal recognition of samesex relationships and of parenting by same-sex couples, is the need to protect children. This argument is, mainly, symbolic as same-sex couples and rainbow families will continue to exist, irrespective of whether they are legally recognised. In fact, increasing numbers of children in Europe are being raised in families comprised of a same-sex couple and it is clear that failing to provide legal recognition to such families will not reduce the numbers of such families but will complicate their lives and will result in a breach of a number of fundamental rights that the children enjoy. As Koppelman has rightly pointed out, '[i]t would be bizarre and ironic for a state to harm actual children in order to make a symbolic point. The legal ties between parents and children should not be affected by any family member's decision to cross state lines'. ${ }^{144}$

There has been considerable social, scientific, and psychological research which argues that the successful raising of a child is not dependent upon the sexual orientation of his or her parents. ${ }^{145}$ Moreover, the ECtHR has pointed out in its caselaw that 'there is currently a broad consensus - including in international law - in support of the idea that in all decisions concerning children, their best interests must be paramount' and has made a reference to Article 24 EUCFR and to the importance of the right of the child to maintain a personal relationship and direct contact with both his/her parents. ${ }^{146}$ The same court has also noted that 'family ties may only be severed in very exceptional circumstances and that everything must be done to preserve personal relations' ${ }^{147}$ Accordingly, the best interests of the child seem to require that the familial ties (s)he has legally established with his/her parents in another country, should be maintained when the family moves to another Member State. Same-sex couples should, therefore, continue to be legally recognised as the joint parents of their children in the host State, not despite the children's best

144

A. Koppelman (above n. 30) 110. See, also, pp. 150-151.

See, most fundamentally, S. Golombok (above n. 8) esp. chapters 2 and 7; paras 47-52 of the Explanatory Memorandum by Mr Jonas Gunnarsson included in Report 'Private and family life: achieving equality regardless of sexual orientation' (Doc. 14620), drafted on 21 September 2018. The Report led to the adoption, by the Parliamentary Assembly of the Council of Europe (PACE), of Resolution 2239 (2018) 'Private and family life: achieving equality regardless of sexual orientation', adopted by PACE on 10 October 2018 (both documents are available online <http://assembly.coe.int/nw/xml/XRef/Xref-DocDetails-EN.asp?FileID=25166\&lang=EN> (accessed on 19.12.2018); the sources referred to in this website <https://whatweknow.inequality.cornell.edu/topics/lgbt-equality/what-does-the-scholarlyresearch-say-about-the-wellbeing-of-children-with-gay-or-lesbian-parents/> (accessed on 25.06.2018); the American Psychological Association Policy Statement on Sexual Orientation, Parents, and Children < http://www.apa.org/about/policy/parenting.aspx > (2004) (accessed on 25.06.2018); N. Gartrell, H. Bos, A. Koh, 'National Longitudinal Lesbian Family Study - Mental Health of Adult Offspring' (2018) 379 The New England Journal of Medicine 297. For a different view see para. 42 of the ECtHR judgment in Fretté v. France, no. 36515/97, 26/5/2002, 2002, though it should be noted that the case was decided more than 15 years ago.

Neulinger and Shuruk v. Switzerland, no. 41615/07, 2010, para. 135.

ibid, para. 136. 
interests, but exactly because this is required, if the children's best interests are taken into account. ${ }^{148}$

In fact, the need to take into account the best interests of the child, can - under EU law - also be used as an independent argument by rainbow families seeking to have the parent-child relationship recognised when they move, since, unlike the ECHR, the Charter does contain a provision - Article 24 EUCFR - which specifically provides that in all actions relating to children their best interests must be a primary consideration. Accordingly, in the EU context, the best interests of the child argument does not need to be solely used as a shield, in order to prevent Member States from justifying their refusal to recognise rainbow families but it can, also, be used as a sword, when arguing that non-recognition amounts to a breach of EU law. Nonetheless, given the vagueness of the principle, which makes it vulnerable to be (ab)used by judges so as to disadvantage the children of rainbow families, ${ }^{149}$ it might be better for rainbow families to base their argument on the right to private and family life and - as will be seen in the next subsection - the prohibition of discrimination on the ground of sexual orientation.

Accordingly, taking into account the ECtHR's interpretation of the right to private and family life, we can argue that the failure of the host EU Member State to recognise the legal links between the child in a rainbow family and both of his parents - as these have been legally established elsewhere - can clearly amount to an unjustified breach of the right to private and family life of the child, as this is laid down under Article 7 EUCFR and the general principles of EU law. ${ }^{150}$

\section{V.3.2. Breach of the Prohibition of Discrimination on the Ground of Sexual Orientation}

In situations where the host Member State refuses to recognise the parental ties between a child of a same-sex couple and both of his/her parents, as these have been legally established elsewhere, this is clearly done because the parents of the child are of the same sex. In other words, Member States which do not allow a same-sex couple to legally establish a family in their territory, and which do not allow a rainbow family lawfully established elsewhere to be recognised as such, do so for the simple reason

148 C. McGlynn (above n. 10) 108. For a clear statement by the ECJ that when Member States apply and/or implement EU secondary legislation, Article 24 EUCFR read together with Article 51 requires them in all its decisions to have the child's best interests as their primary consideration see Case C-648/11 MA and others EU:C:2013:367, paras 57-59.

As another commentator has noted, 'the vagueness of the principle [of the best interests of the child] means it can just as easily be used as a "fulcrum for regression" as it can for progression' - M. Woolf, "Coming of age? - the principle of "the best interests of the child" (2003) 2 European Human Rights Law Review 205, 208. For a criticism of the principle of the best interests of the child when applied in situations involving parenting by same-sex couples see I. Isailovic, 'Children's rights and LGBTI persons' rights: few thoughts on their "integration"' in E. Brems, E. Desmet and W. Vandenhole (eds), Children's Rights Law in the Global Human Rights Landscape: Isolation, Inspiration, Integration? (Routledge, 2017) 198-201.

For a similar argument see P. Dunne (above n. 27) 43-44. 
that the couple that is founding the family is comprised of two persons of the same sex. If the parents of the child were an opposite-sex couple, in the vast majority of cases they would both be legally recognised as the parents of the child, even if the child was adopted or was conceived via assisted procreation methods. Accordingly, the children of same-sex couples are expressly treated worse than the children of opposite-sex couples and, thus, there is discrimination which is directly based on the fact that the parents of the children who are treated worse are a same-sex couple.

As Robert Wintemute noted in his expert testimony in the Atala Riffo case before the Inter-American Court of Human Rights, 'sexual orientation also includes conduct. This means that protection against discrimination based on sexual orientation is not only about less favourable treatment for being lesbian or gay. It also covers discrimination because an individual acts on their sexual orientation, by choosing to engage in consensual sexual activity in private, or to enter into a long-term couple relationship with a partner of the same sex'. ${ }^{151}$ Accordingly, discrimination against rainbow families is discrimination based on the fact that the LGB parents in a rainbow family have acted on their sexual orientation by entering into a long-term couple relationship with a partner of the same sex and is, thus, a form of discrimination on the ground of sexual orientation.

Hence, the children of same-sex couples face discrimination because of the sexual orientation of their parents and, in particular, they face discrimination on the ground of sexual orientation by association with their LGB parents. As established by the ECJ in the Coleman case, ${ }^{152}$ the prohibition of discrimination under Directive 2000/78 153 the EU instrument which prohibits discrimination on, inter alia, the ground of sexual orientation in the context of employment - includes, also, discrimination by association. There is no reason why this should not, also, be the case for Article 21 EUCFR, which, generally, prohibits discrimination on, inter alia, the ground of sexual orientation. ${ }^{154}$

Unlike Article $14 \mathrm{ECHR}$, which is not a free standing provision and, thus, requires the discrimination complained of to be experienced with regards to the enjoyment of one of the rights provided by the ECHR, ${ }^{155}$ Article 21 EUCFR is a free standing provision and, thus, for its breach it suffices that an EU institution or a Member State - when implementing EU law - discriminates on the ground of, inter alia, sexual orientation. Moreover, Article 20 EUCFR provides that 'Everyone is equal before the law' and

151 Expert testimony rendered by expert Robert Wintemute, September 16, 2011. Quoted by the Inter-American Court of Human Rights in Case of Atala Riffo and Daughters v. Chile Inter-Am. Comm. HR, Case 12.502, para. 134. Case C-303/06, Coleman EU:C:2008:415.

153 Above n. 97.

154 There has not been a case to date which precedes the recognition of the EUCFR as a legally binding document and which involved the need to establish whether the prohibition of discrimination on the ground of sexual orientation is a fundamental human right protected as a general principle of EU law.

155 Protocol 12 of the ECHR is a free-standing provision prohibiting discrimination on a number of grounds, however, it has only been ratified by a minority of ECHR signatory states. 
McGlynn has noted that this can be read as, inter alia, requiring that 'All children are equal before the law'. ${ }^{156}$ Despite the fact that both of the above provisions provide for self-standing rights to equality and non-discrimination, they can, of course, be read together with one or more of the other rights laid down in the Charter. For instance, in situations where the family cannot move together in the territory of another Member State due to the refusal to recognise legally the ties between a child and one of his/her parents, there is discrimination on the ground of sexual orientation as regards the enjoyment of the right to family life. As noted by the ECtHR, 'the mutual enjoyment by parent and child of each other's company constitutes a fundamental element of family life' and 'domestic measures hindering such enjoyment amount to an interference with the right protected by Article 8 ' of ECHR. ${ }^{157}$ Accordingly, in situations where a rainbow family is not allowed to move together in the territory of another Member State in circumstances where a similarly situated family comprised of an opposite-sex couple would, there is discrimination on the ground of sexual orientation as regards the right to family life. ${ }^{158}$ As another commentator has rightly noted, 'one should wonder whether, even if the State does not recognize same-sex marriage or unions, there appears any reason why the child should be deprived of one parent just because the couple is formed by two people of the same gender'. ${ }^{159}$

Irrespective of which line of argument will be pursued - whether the prohibition of discrimination on the ground of sexual orientation is employed alone or with another fundamental human right - the important question is whether the host Member State may, nonetheless, be justified in drawing a distinction between the children of rainbow families and the children of opposite-sex couples, in situations where there has been an exercise of EU free movement rights.

The ECtHR has made it clear that it considers discrimination based on sexual orientation to be as serious as discrimination on the grounds of 'race, origin or colour', ${ }^{160}$ and it has also repeatedly held that 'differences based on sexual orientation require particularly serious reasons by way of justification' ${ }^{161}$ This means that where a difference in treatment is based on sexual orientation, the State's margin of appreciation is narrow and this strict test will rarely - if ever - be satisfied.

The Member States would - most probably - rely on the same arguments as they would, when justifying an interference of the rights to private and family life: the need to protect and encourage the traditional family and the need to protect the rights of

156 C. McGlynn (above n. 10) 71.

157 Schalk and Kopf (above n. 75) para. 91.

158 In such situations, it would be unlikely to find a breach of the right to family life alone, as it is well-established that States are not under an obligation under Article 8 ECHR to authorise a family reunion in their territory - Gül v. Switzerland, no. 23218/94, 1996. The same approach has been followed in the EU context - see Carpenter (above n. 90).

M. M. Winkler (above n. 12)

160 Vejdeland and Others v. Sweden, no. 1813/07, 2012, para. 55.

161 Gas and Dubois (above n. 7) para. 59; Smith and Grady v. UK, nos 33985/96 and 33986/96, 2000, para. 90; Karner v. Austria (above n. 137) para. 37; Vallianatos v. Greece (above n. 75) para. 77; Kozak v. Poland, no. 13102/02, 2010, para. 92. 
the children. The arguments made in the previous sub-section for rejecting these aims as sufficient justifications are, naturally, applicable in this context as well, and, therefore, will not be repeated here. When examining this discrimination argument, the injustice suffered by the children of rainbow families becomes even more obvious, as they are directly compared with the children of parents who are not in a same-sex relationship. As Judge Villiger very rightly noted in his dissenting opinion in the Gas and Dubois v. France case, "how can children help it that they were born of a parent of a same-sex couple rather than of a parent of a heterosexual couple? Why should the child have to suffer for the parents' situation?'. ${ }^{162}$ Or, as asked by another commentator, 'Why prejudice children living in a certain kind of relationship'? ${ }^{163}$

Accordingly, the children of rainbow families should not be 'penalised in [their] daily existence' ${ }^{164}$ simply because of their association with their parents who are of homosexual sexual orientation. Penalising the children of same-sex couples is an ineffectual way of deterring same-sex couples from having a family, as the desire to have a child - in same-sex couples which have such a desire - is very strong, as can be gathered from the fact that having a child together is not naturally possible and, thus, the couple often has to undergo through cumbersome and costly procedures. Hence, same-sex couples are unlikely to be discouraged from having a family as a result of the legal difficulties that they will face, ${ }^{165}$ and, thus, Member State policies that harm children for the sake of regulating the sexual behaviour of their parents should be condemned.

Just as the children of opposite-sex couples that move to the host Member State in exercise of their free movement rights, have the right to benefit from family reunification rights granted by EU law and, once admitted, to be recognised as the children of both of their parents, in the same way, the children of same-sex couples that move to another Member State should be able to maintain the legal ties lawfully established between them and their parents elsewhere and to enjoy the rights that ensue from such a recognition. ${ }^{166}$

162 Dissenting opinion of Judge Villiger in Gas and Dubois v. France (above n. 7).

K. Lundström, 'Family Life and the Freedom of Movement of Workers in the European Union' (1996) 10 International Journal of Law, Policy and the Family, 250, 262.

164 Wagner v. Luxembourg (above n. 127) para. 158.

165 For a similar argument in the US context see L. Gonzalez (above n. 10) 307-308.

166 Moreover, viewing the matter from the perspective of the parents of the child, just as a person seeking to adopt cannot be prevented from doing so merely on the grounds of his or her (homosexual) sexual orientation - as established in E.B. v. France (above n. 76) - it would seem that a person cannot be deprived of the familial links that (s)he has lawfully established in another country merely on the grounds of his or her (homosexual) sexual orientation. Nonetheless, it should be highlighted that E.B. may be somewhat limited in that on the facts of the case, national legislation established a right for 'any person' to adopt and - as Johnson has noted - the case does not establish a right for single homosexuals to adopt but merely ensures that when there is a right for everyone to adopt, the sexual orientation of a person is not relied on as a ground to refuse that right - see P. Johnson (above n. 136) 134. 


\section{V.3.3. Breach of Rights Protected Under the UN Convention on the Rights of the Child}

The Convention on the Rights of the Child (CRC) is a human rights Treaty adopted by the UN General Assembly in 1989. It entered into force in 1990 and, since then, has received near-global ratification. It sets out the civil, political, economic, social, health and cultural rights of children, 'child' being defined in its Article 1 as 'every human being below the age of eighteen years unless under the law applicable to the child, majority is attained earlier'. There is no court which oversees compliance with the Convention, but, rather, the Committee on the Rights of the Child which is a body of eighteen independent experts, monitors and reports on the progress made by states parties. $^{167}$

All EU Member States have signed and ratified the CRC and are, thus, bound by it as a matter of international law. Moreover, although the EU is not party to it, the ECJ has pointed out that it 'has already recognised that the Convention on the Rights of the Child is binding on each of the Member States and is one of the international instruments for the protection of fundamental rights of which it takes account in applying the general principles of Community law'. ${ }^{168}$

Accordingly, the rights laid down in the CRC - and the interpretation of those rights by the Committee on the Rights of the Child - can, clearly, be relied on to strengthen the position of the children of rainbow families, in situations where the host Member State legally severs the familial ties between them and (one or both of) their parents. ${ }^{169}$ In particular, the Convention can be used as a source of valuable interpretive guidance by the ECJ and the other EU institutions when determining the interpretation of the rights that rainbow families derive from EU law.

The CRC, obviously, provides some of the rights that children already enjoy under EU law, such as, the right to private and family life (Article $16 \mathrm{CRC}$ ) and the best interests of the child (Article $3 \mathrm{CRC}$ ). ${ }^{170}$ However, it also includes a number of other rights (or more detailed rights) which can, clearly, bolster the argument of rainbow families who seek cross-border legal recognition when they exercise their EU free movement rights.

For a more detailed analysis of the CRC see T. Buck, International Child Law (Palgrave, 2014) Chapter 3.

Case C-244/06 Dynamic Medien EU:C:2007:515, para. 90. For a summary of the role of the CRC in the development of the EU's child policy see EU Agency for Fundamental Rights, 'Handbook on European law relating to the rights of the child', $<$ https://fra.europa.eu/en/publication/2015/handbook-european-law-child-rights> pp. 26-28, (accessed on 11.01.2019).

N. Kogovšek Šalamon, White Paper 'Rights on the Move - Rainbow Families in Europe', The Peace Institute (01.01.2015) <http://www.mirovni-institut.si/en/publications/white-paperrights-on-the-move-rainbow-families-in-europe/> (accessed on 17.01.2019) page 28.

Guidance on the interpretation of the principle of the best interests of the child has been provided by the Committee on the Rights of the Child in its General comment No. 14 (2013) on the right of the child to have his or her best interests taken as a primary consideration (art. 3, para 1), 29 May 2013. 
Article 2(2) CRC contains one of the foundational principles of the Convention (nondiscrimination) and provides that 'States Parties shall take all appropriate measures to ensure that the child is protected against all forms of discrimination or punishment on the basis of the status, activities, expressed opinions, or beliefs of the child's parents, legal guardians, or family members'. Although the above list of grounds does not include sexual orientation, the Committee on the Rights of the Child has confirmed in one of its (recent) General Comments that children are entitled to the enjoyment of their rights 'regardless of the children's or their parents' ... sexual orientation', 171 whilst, in another General Comment, it recognised that children may 'suffer the consequences of discrimination against their parents, for example if children have been born out of wedlock or in other circumstances that deviate from traditional values' ${ }^{172}$ Accordingly, this can strengthen the argument of the children of rainbow families that they must not be discriminated against because of the sexual orientation of their parents, in situations where the family exercises EU free movement rights.

The same argument can, also, be bolstered by Article 8(1) CRC which protects the right to identity and provides that 'States Parties undertake to respect the right of the child to preserve his or her identity, including nationality, name and family relations as recognized by law without unlawful interference'. Of course, the question here is whether 'family relations' do - for the purposes of the CRC - include relations among the members of a rainbow family. The approach of the Committee on the Rights of the Child towards the notion of the 'family' seems to be flexible enough to include rainbow families, despite the fact that this has not been explicitly acknowledged, possibly due to the fact that the CRC has been ratified by a very large number of countries around the world, some of which are deeply homophobic, and, thus, an explicit statement to this effect might give rise to an overly negative reaction on their part. When interpreting this provision, the Committee noted that ' $t$ ] he basic institution in society for the survival, protection and development of the child is the family. When considering the family environment the Convention reflects different family structures arising from the various cultural patterns and emerging familial relationships. In this regard the Convention refers to the extended family and the community and applies to situations of nuclear family, separated parents, single parent family, common law family and adoptive family'. ${ }^{173}$ Reflecting on this, one commentator has noted that the above passage 'does not restrict the definition of "parents" to heterosexual couples. Although there is no reference to people of the same sex, there is also no express exclusion of such relationships. .... [T]

171 Joint general comment No. 3 (2017) of the Committee on the Protection of the Rights of all Migrant Workers and Members of their Families and No. 22 (2017) of the Committee on the Rights of the Child on the general principles regarding the human rights of children in the context of international migration, 16 November 2017, para. 21.

172 Committee on the Rights of the Child General Comment No. 7 (2005) Implementing child rights in early childhood, 20 September 2006, para. 12

173 Committee on the Rights of the Child, Role of the Family in the Promotion of the Rights of the Child, $7^{\text {th }}$ Session, 10 October 1994, CRC/C/24 (1994), para. 2.1. See, also, General comment No. 14 (2013) (above n. 170), Section V.A.1(c). 
in the final text of article 8 which demands that the meaning of "familial relations" be restricted to biological ties'. ${ }^{174}$

Finally, Article 9(1) CRC provides that 'States Parties shall ensure that a child shall not be separated from his or her parents against their will, except when competent authorities subject to judicial review determine, in accordance with applicable law and procedures, that such separation is necessary for the best interests of the child'. ${ }^{175}$ This provision - especially when read together with Article 2(1) CRC - can help to strengthen the argument of the children of rainbow families that they should not be discriminated against on the ground of the sexual orientation of their parents when the family claims family reunification rights under EU law.

\section{Conclusion}

Despite the fact that same-sex couples have often succeeded in creating and sustaining meaningful family relationships, in some EU Member States the law does not recognise relationships between same-sex partners, nor does it protect relationships between same-sex couples and their children. As has been explained in this article, EU law cannot require those Member States to make provision in their laws for rainbow families to be legally established as families in their territory, as this is a matter that falls squarely within the regulatory purview of the Member States. Nonetheless, families which are recognised as families under one legal system, cannot have their status as a family and the rights attached to that status, challenged or ignored in the EU Member State to which they move. This creates gross inconsistencies across State lines and great uncertainties for rainbow families. In addition, it gives rise to a breach of the EU free movement rights to which Union citizens are entitled, as well as to fundamental human rights which are protected under EU law.

A court or legislature cannot stop gays or lesbians from forming families. The law's unwillingness to legally recognise and preserve parent-child relationships in rainbow families that move across borders comes contrary to the best interests of the children of such families and breaches a number of fundamental rights they enjoy under EU law. It is, therefore, necessary for EU judges and/or the EU legislature to fashion rules and principles that reflect the reality of the lives of the children of rainbow families, when such families move between EU Member States. The difficulty with this is that

174 J. Tobin, 'Recognising Same-Sex Parents: Bringing legitimacy to the law' (2008) 33 Alternative Law Journal 36, 37-38.

175 For an analysis of the meaning of this Article in the context of international migration see Joined general comment No. 4 (2017) of the Committee on the Protection of the Rights of All Migrant Workers and Members of Their Families and No. 23 (2017) of the Committee on the Rights of the Child on State obligations regarding the human rights of children in the context of international migration in countries of origin, transit, destination and return, 16 November 2017, paras 27-38. 
in order for EU legislation to pass, it needs to have, at least, ${ }^{176}$ the support of the majority of EU Member States in the Council. And given that it is only in a minority of EU Member States that there is currently full legal recognition of the parental rights of same-sex couples, it is highly unlikely that the necessary majority will be achieved.

There is, therefore, a need for an alternative EU law response on the matter. In the absence of a reference for a preliminary ruling to the ECJ by a national court before which the issue is raised, a first step towards the right direction can come from the (other) EU institutions. In particular, the European Commission should take action under the Article 258 TFEU procedure against the defaulting EU Member States and, if they continue to breach the rights that the children of rainbow families enjoy under EU law, an action should be brought before the ECJ asking it to declare that their refusal to legally recognise the familial ties between a child and both of his (same-sex) parents when they move to their territory, amounts to a breach of EU law. In addition, the Commission should issue a Communication clarifying that the terms used in free movement case-law and secondary legislation which governs the right of families to move freely between Member States (e.g. 'primary carer', 'direct descendants', and 'ascendants in the direct line') are inclusive of rainbow families. ${ }^{177}$ This will ensure that when rainbow families move between EU Member States, they will be treated in the same way as the families of opposite-sex couples, as regards the grant of family reunification rights as well as rights to which families are entitled after they are admitted into the host Member State: as long as the familial ties among a child and both of his/her parents are legally recognised in a country either within or outside the $\mathrm{EU}$, they must continue to be recognised, also, when the family exercises EU free movement rights and the family must not be separated or deprived of various entitlements simply because the parental roles are played by persons of the same sex.

Only in this way will the children's need for continuity and stability be served and EU law will become an instrument for contesting the heteronormative morality prevailing in the majority of EU Member States. After all, the EU claims to be 'founded on the values of' inter alia respect for human dignity, equality, and respect for human rights, including the rights of persons belonging to minorities ${ }^{178}$ and this, clearly, cannot be read to mean that this is only human dignity, equality and human rights for some. Moreover, Article 10 TFEU provides that 'In defining and implementing its policies and activities, the Union shall aim to combat discrimination based on sex, racial or ethnic origin, religion or belief, disability, age or sexual orientation' ${ }^{179}$ Children who live outside the traditional nuclear family should not be marginalised and excluded from many of the entitlements and rights they derive from EU law and they should not live

176 And, if a legal basis which requires unanimity (e.g. Article 19 TFEU or Article 81 TFEU) is used as the only or one of the legal bases for the legislation, then the proposal will need to be approved by all EU Member States.

177 A similar step has recently been taken by the Council of Europe Parliamentary Assembly in paras 2 and 4.5 of Resolution 2239 (2018) (above n. 145). See, also, paragraphs 6, 37 and 67 of the Explanatory memorandum by Mr Jonas Gunnarsson, rapporteur, attached to the Resolution (above n. 145).

Article 2 TEU.

179 Emphasis added. 
in fear that if their family moves to another EU Member State their legal links with one or both of their parents will be severed. 